\title{
๖.Derecho Evolving from a Mesocyclone-A Study of 11 August 2017 Severe Weather Outbreak in Poland: Event Analysis and High-Resolution Simulation $\mathscr{O}$
}

\author{
Mateusz TAszarek, ${ }^{\mathrm{a}, \mathrm{g}}$ NATAlia Pilguj, ${ }^{\mathrm{b}, \mathrm{g}}$ Juliusz Orlikowski, ${ }^{\mathrm{c}}$ Artur Surowiecki,,${ }^{\mathrm{d}, \mathrm{g}}$

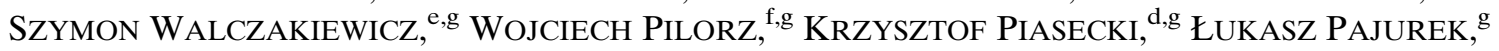 \\ AND MAREK PÓŁROLNICZAK ${ }^{\mathrm{a}}$ \\ ${ }^{a}$ Department of Climatology, Adam Mickiewicz University, Poznań, Poland \\ ${ }^{\mathrm{b}}$ Department of Climatology and Atmosphere Protection, University of Wroctaw, Wroctaw, Poland \\ ${ }^{\mathrm{c}}$ Department of Electrochemistry, Corrosion and Materials Science, Gdańsk University of Technology, Gdańsk, Poland \\ ${ }^{\mathrm{d}}$ Department of Climatology, University of Warsaw, Warsaw, Poland \\ ${ }^{\mathrm{e}}$ Climatology and Meteorology Unit, University of Szczecin, Szczecin, Poland \\ ${ }^{\mathrm{f}}$ Department of Climatology, Faculty of Earth Sciences, University of Silesia, Katowice, Poland \\ ${ }^{\mathrm{g}}$ Skywarn Poland, Warsaw, Poland
}

(Manuscript received 16 September 2018, in final form 26 March 2019)

\begin{abstract}
This study documents atmospheric conditions, development, and evolution of a severe weather outbreak that occurred on 11 August 2017 in Poland. The emphasis is on analyzing system morphology and highlighting the importance of a mesovortex in producing the most significant wind damages. A derecho-producing mesoscale convective system (MCS) had a remarkable intensity and was one of the most impactful convective storms in the history of Poland. It destroyed and partially damaged 79700 ha of forest ( 9.8 million $\mathrm{m}^{3}$ of wood), 6 people lost their lives, and 58 were injured. The MCS developed in an environment of high $0-3-\mathrm{km}$ wind shear (20-25 m s$\left.~^{-1}\right)$, strong $0-3-\mathrm{km}$ storm relative helicity $\left(200-600 \mathrm{~m}^{2} \mathrm{~s}^{-2}\right)$, moderate most-unstable convective available potential energy (1000-2500 $\left.\mathrm{J} \mathrm{kg}^{-1}\right)$, and high precipitable water (40-46 mm). Within the support of a midtropospheric jet, the MCS moved northeast with a simultaneous northeastward inflow of warm and very moist air, which contributed to strong downdrafts. A mesocyclone embedded in the convective line induced the rear inflow jet (RIJ) to descend and develop a bow echo. In the mature stage, a supercell evolved into a bookend vortex and later into a mesoscale convective vortex. Swaths of the most significant wind damage followed the aforementioned vortex features. A high-resolution simulation performed with initial conditions derived from GFS and ECMWF global models predicted the possibility of a linear MCS with widespread damaging wind gusts and embedded supercells. Simulations highlighted the importance of cloud cover in the preconvective environment, which influenced the placement and propagation of the resulting MCS.
\end{abstract}

\section{Introduction}

\section{a. Overview}

Each year, Poland experiences 150 days with thunderstorms (Taszarek et al. 2015), among that, according

D Denotes content that is immediately available upon publication as open access.

Supplemental information related to this paper is available at the Journals Online website: https://doi.org/10.1175/MWR-D-18-0330.s1.

Corresponding author: Mateusz Taszarek, mateusz.taszarek@ amu.edu.pl to the European Severe Weather Database (ESWD; Dotzek et al. 2009), approximately 600 severe convective wind gusts are reported. Such events are the most frequent from May to August and normally peak in July in the late afternoon hours (Celiński-Mysław and Palarz 2017; Taszarek et al. 2019). Damaging winds originating from the thunderstorm's outflow can be produced even by the ordinary cells, but most frequently they accompany supercells (a thunderstorm that has a deep and persistent rotating updraft; Doswell and Burgess 1993) and mesoscale convective systems (MCS; Zipser 1982; Houze 1993). MCSs typically consist of an embedded vertical mesoscale circulation (Houze 2004) and exhibit a variety of distinct radar echo patterns such as squall lines, bow echoes (Fujita 1978) or line echo wave 
patterns (Nolen 1959; Funk et al. 1999; Atkins et al. 2004) in trailing, as well as leading and parallel stratiform precipitation modes (Parker and Johnson 2000).

Many studies indicated that mid- and low-level mesovortices (meso- $\gamma$ scale, i.e., $2-20 \mathrm{~km}$ in horizontal scales; Orlanski 1975) may form within the leading edge of linear MCSs and that downward or upward tilting of baroclinically generated horizontal vorticity within outflow zone may be a primary cause of their formation (Weisman 1993; Trapp and Weisman 2003; Atkins et al. 2005; Atkins and St. Laurent 2009b; Xu et al. 2015a,b; Schenkman and Xue 2016). Downdrafts play an important role in generating vertical rotation near the surface since the downward tilting seems to be more efficient compared to upward tilting (Davies-Jones 1982a,b; Walko 1993; Markowski 2002). Downdrafts contribute also to enhancement in a low-level convergence zones (inducing stretching of vertical vorticity) and are responsible for severe wind gusts near the surface. Damaging winds are known to be associated with a rear inflow jet (RIJ; Weisman 1992), which on radar scans is usually marked as a rear inflow notch and/or bow echo (Fujita 1978, 1979; Xu et al. 2015a). In certain situations, downward pressure perturbation force induced by bookend (line-end) mesovorticies may cause RIJ to descend to the ground and produce strong winds (Skamarock et al. 1994; Weisman and Davis 1998; Grim et al. 2009; Meng et al. 2012; Xu et al. 2015a,b). The most damaging winds tend to be found within a strong lowlevel mesovortex coinciding with RIJ on the edge of the bow echo (Weisman and Trapp 2003; Davis et al. 2004; Atkins et al. 2004, 2005; Wakimoto et al. 2006a,b; Wheatley et al. 2006; Atkins and St. Laurent 2009a,b; French and Parker 2014; Xu et al. 2015a,b). The line-end mesovortex with a large and persistent rotation may sometimes evolve into a larger feature called mesoscale convective vortex (MCV; Davis and Trier 2007). French and Parker (2014) also found that a supercell embedded in a squall line may locally enhance RIJ and lead to a broad swaths of damaging surface winds.

Long-lived MCSs that are persistent in producing widespread damaging winds are known as derechos (Johns and Hirt 1987). European studies on derecho have focused mainly on the analysis of environmental conditions (Gatzen 2004; Punkka et al. 2006; López 2007; Púčik et al. 2011; Simon et al. 2011; Hamid 2012; Gospodinov et al. 2015; Toll et al. 2015; Mathias et al. 2017; Celiński-Mysław et al. 2018) and multiannual summaries (Gatzen et al. 2011; Gatzen 2013; CelińskiMysław and Matuszko 2014; Celiński-Mysław and Palarz 2017). The results from these studies indicate that a few such events occur each year in Europe including Poland.
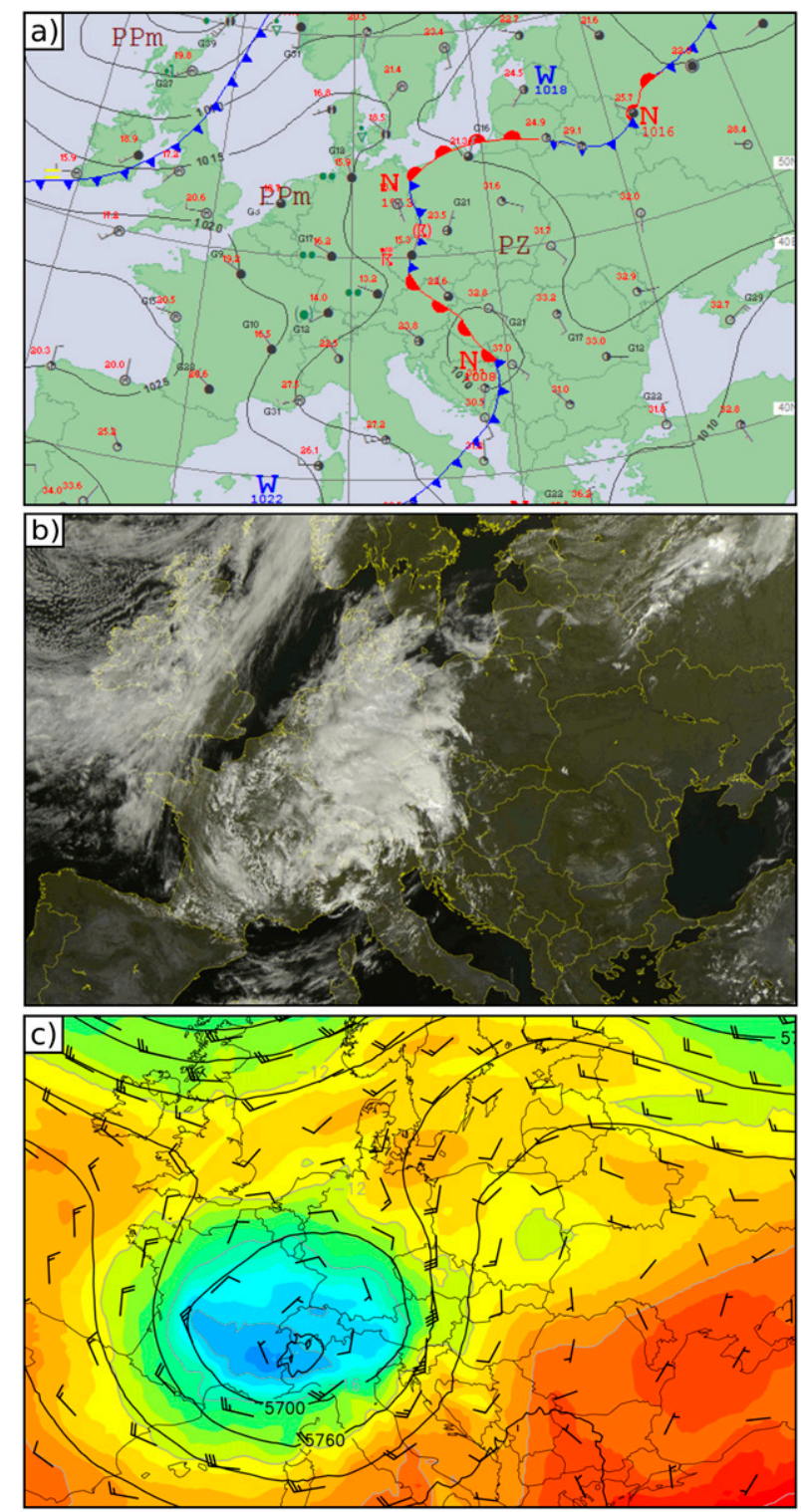

FIG. 1. (a) Synoptic map at 1200 UTC 11 Aug 2017; W-high pressure, $\mathrm{N}$-low pressure, $\mathrm{PZ}$ - tropical air mass, $\mathrm{PPm}$-polar marine air mass (source: Polish Institute of Meteorology and Water Management). (b) Meteosat Second Generation High-Resolution Visible (MSG HRV) image from the same date and hour as previous (source: Sat24.com). (c) Geopotential height (contours), temperature (shaded), and wind vectors (barbs) at $500 \mathrm{hPa}$ from the NCEP FNL analysis.

\section{b. Derecho criteria}

First researchers who developed derecho criteria were Johns and Hirt (1987). Modifications of their definition have been later applied by Bentley and Mote (1998), Evans and Doswell (2001), and Coniglio and Stensrud (2004). The most recent definition proposed by Corfidi et al. (2016) is as follows: "Derecho is a family of 

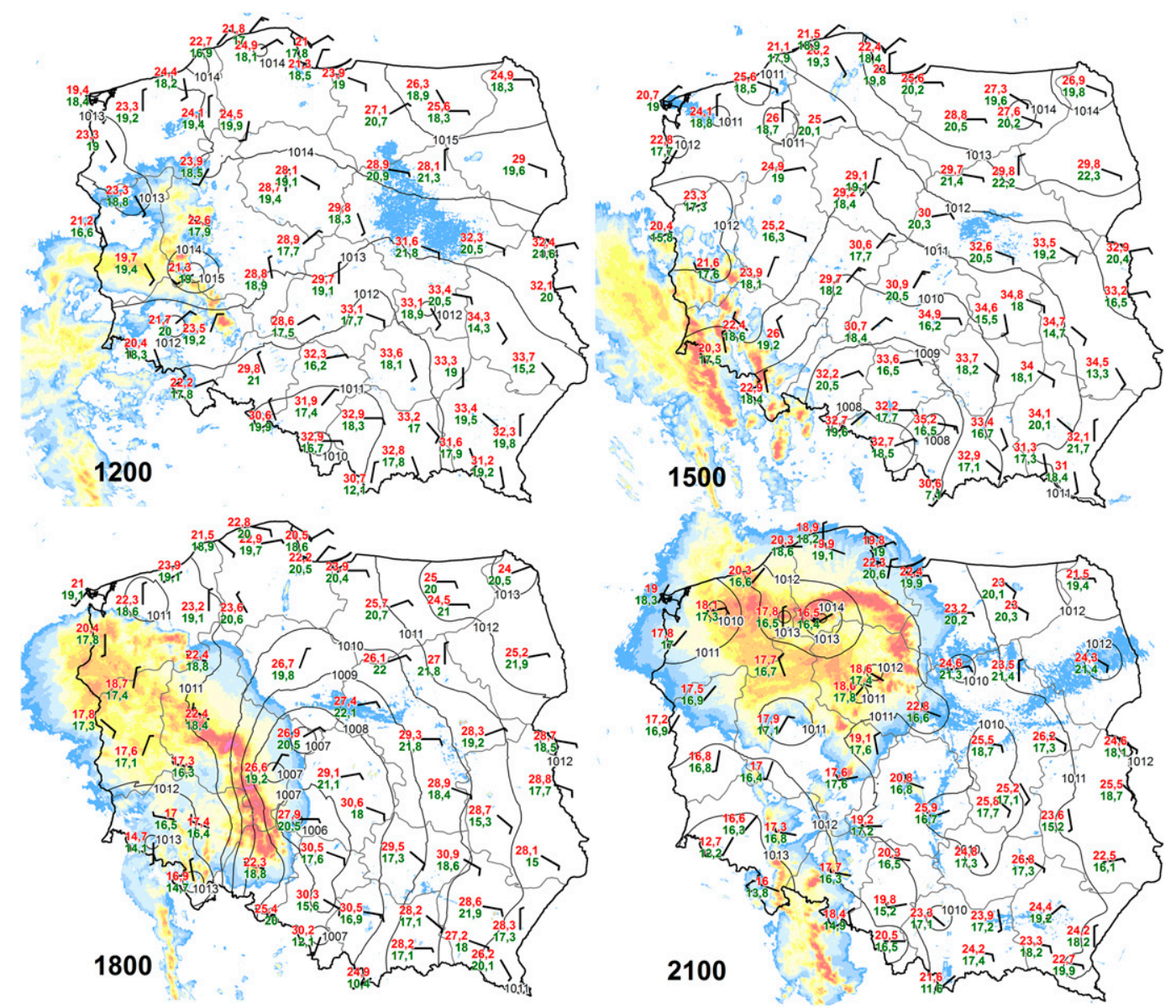

FIG. 2. Surface synoptic observations and interpolated mean sea level pressure at 1200, 1500, 1800, and 2100 UTC 11 Aug 2017. Shaded transparent area denotes maximum reflectivity from POLRAD network.

damaging downburst clusters associated with a forwardpropagating MCS that, during part of its existence, displays evidence of one or more sustained bow echoes with mesoscale vortices and/or rear-inflow jets. The damage swath must be nearly continuous, at least $100 \mathrm{~km}(\sim 60 \mathrm{mi}$ or about $1^{\circ}$ latitude) wide along most of its extent, and $650 \mathrm{~km}$ ( $\sim 400 \mathrm{mi})$ long. The damage also must occur after any preliminary storms have organized into a cold-pool-driven MCS.” (p. 938). The most common ingredients for a wellorganized MCS are sufficient amounts of moisture in the boundary layer, steep low and midlevel temperature lapse rates, strong vertical wind shear, a persistent lifting mechanism, and a parallel orientation between deeplayer wind and shear vectors leading to a fast system propagation (Evans and Doswell 2001; Kuchera and Parker 2006; Cohen et al. 2007; Coniglio et al. 2010; Púčik et al. 2015; Taszarek et al. 2017). A wind shear with a magnitude of approximately $15 \mathrm{~m} \mathrm{~s}^{-1}$ in a $0-3-\mathrm{km}$ layer is considered conducive for a long-lived linear MCS capable of producing widespread wind damage (Coniglio and Stensrud 2001; Weisman and Rotunno 2004; Weisman et al. 2013; Mathias et al. 2017; Celiński-Mysław et al. 2018). Depending on the environmental conditions, we can distinguish a progressive derecho typical for high thermodynamic instability, a serial derecho where the wind shear and synoptic-scale lift play a dominant role, and a hybrid derecho that is a mixture of both (Johns and Hirt 1987; Johns 1993).

\section{c. Predictability}

Convective parameterization in numerical weather prediction (NWP) models has a negative effect on simulating cold pools and thus convective initiation (Weisman et al. 1997). Better results are provided with highresolution nonhydrostatic and convection-permitting models (Kain et al. 2006; Clark et al. 2009; Warren et al. 2014; Leutwyler et al. 2016; Mathias et al. 2017) where a successful simulation of MCS and its corresponding important mesoscale features can be achieved with a horizontal resolution of $3-4 \mathrm{~km}$. In such resolution fluxes of heat, moisture, and momentum can be reliably resolved and improve simulations of MCSs (Weisman et al. 2008, 

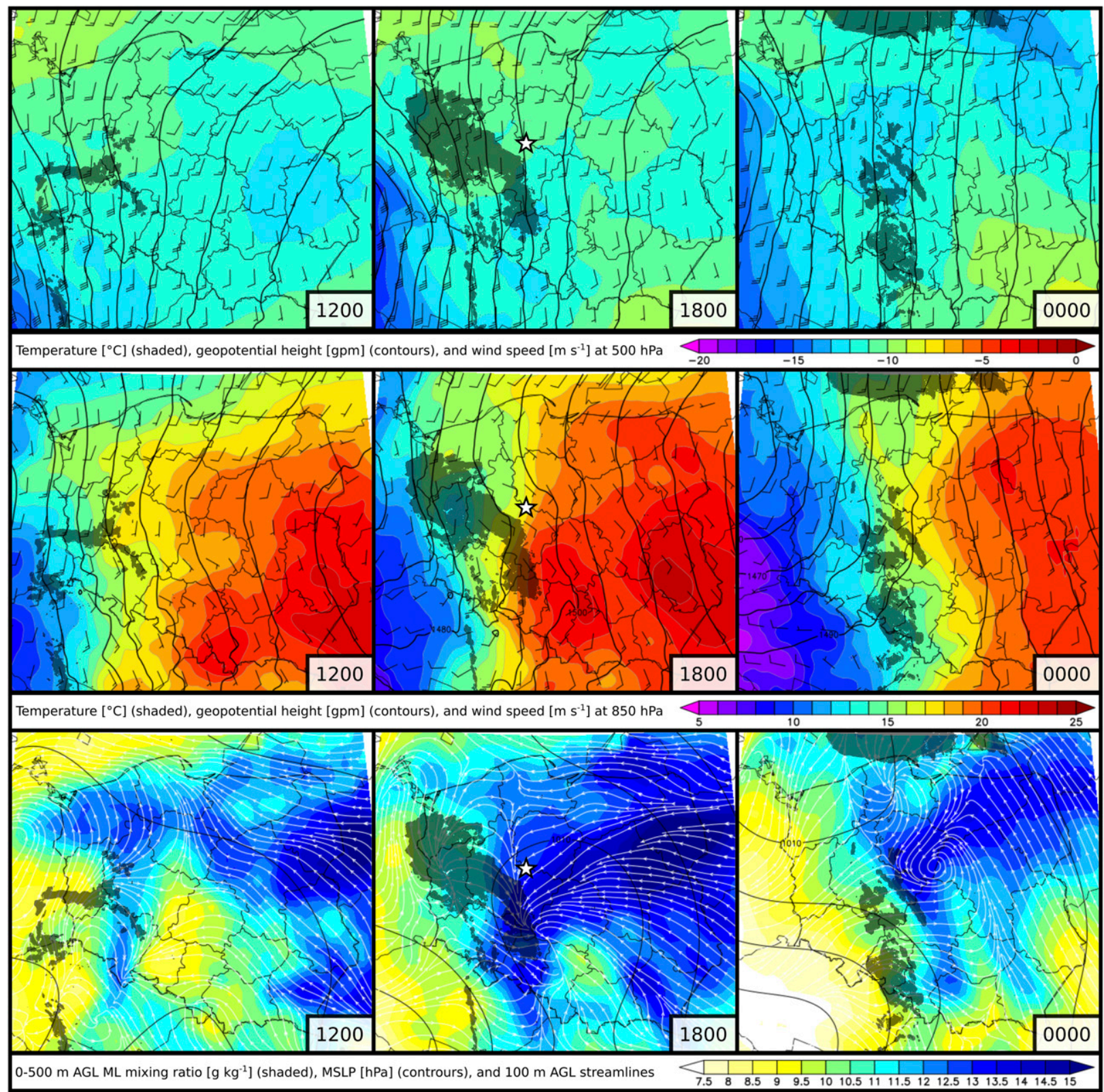

FIG. 3. (top) Geopotential height (contours), temperature (shaded), and wind vectors (barbs) at 500 hPa. (middle) Geopotential height (contours), temperature (shaded), and wind vectors (barbs) at $850 \mathrm{hPa}$. (bottom) Mean sea level pressure (contours), 0 $500 \mathrm{~m}$ AGL ML mixing ratio (shaded), and $100 \mathrm{~m}$ AGL streamlines. Based on (left) 1200 UTC 11 Aug, (center) 1800 UTC 11 Aug, and (right) 0000 UTC 12 Aug 2017 NCEP FNL analysis. Star symbol denotes location and hour for which model sounding is presented in Fig. 5. Transparent black polygons denote area of radar reflectivity higher than $25 \mathrm{dBZ}$ (derived from POLRAD network).

2013; Toll et al. 2015). Several studies can be found, where predictability of MCSs within a convectionpermitting resolution is provided. In spite of limitations associated with initial conditions and physical parameterizations, in many studies it was possible to perform a successful MCS forecast along with mesoscale features such as MCV, RIJ or bow echo (e.g., Melhauser and Zhang 2012; Weisman et al. 2013; French and Parker 2014; Snively and Gallus 2014; Xu et al. 2015a,b, among others). Weisman et al. (2008) used the Weather Research and Forecasting (WRF) Model (Skamarock et al. 2008) and a horizontal resolution of $4 \mathrm{~km}$ to perform 0-36-h real-time explicit convective forecasts and concluded that a significant improvement was observed 

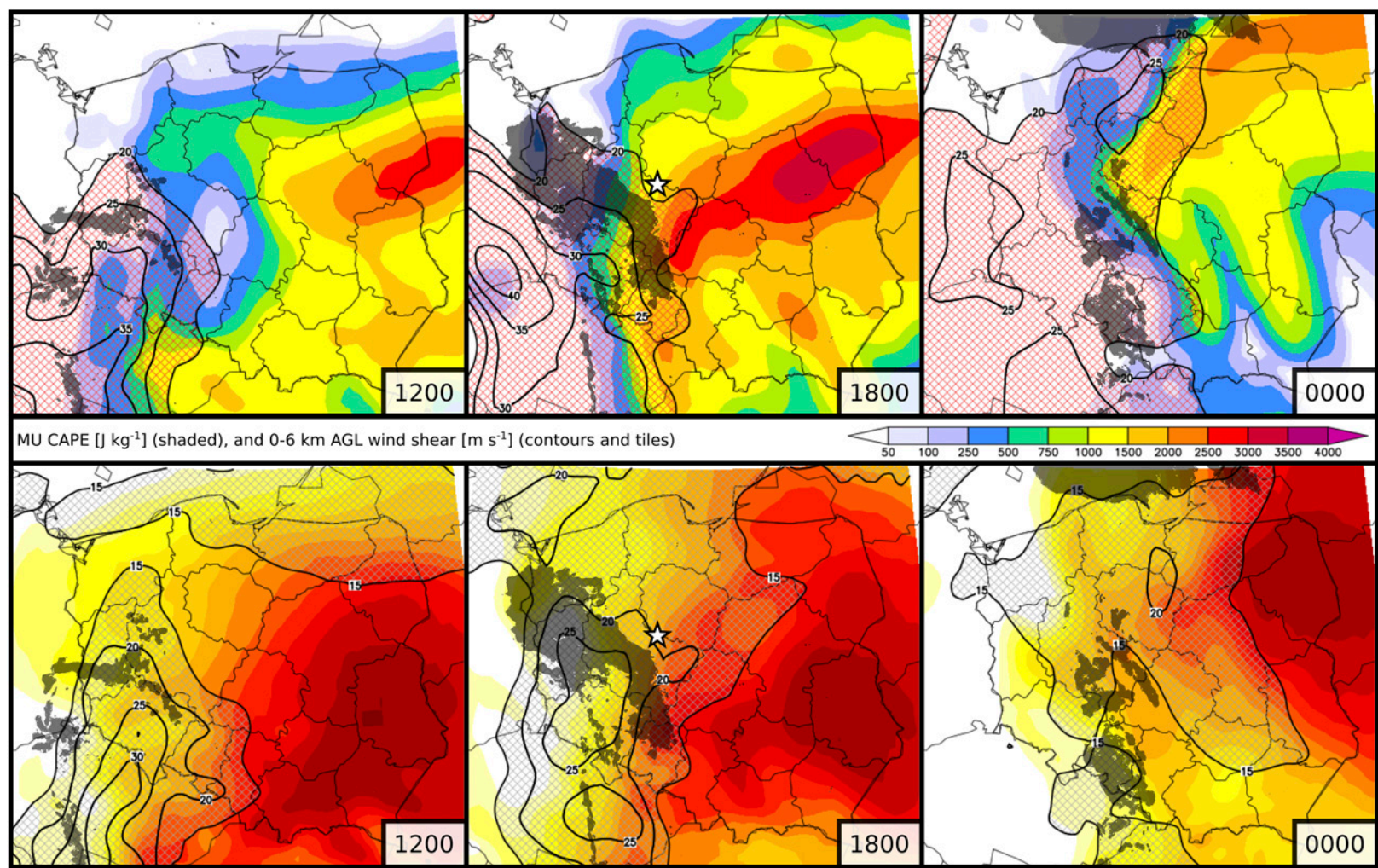

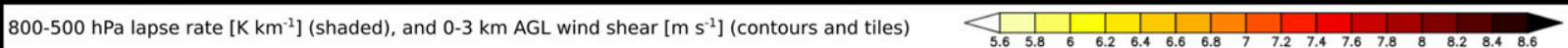

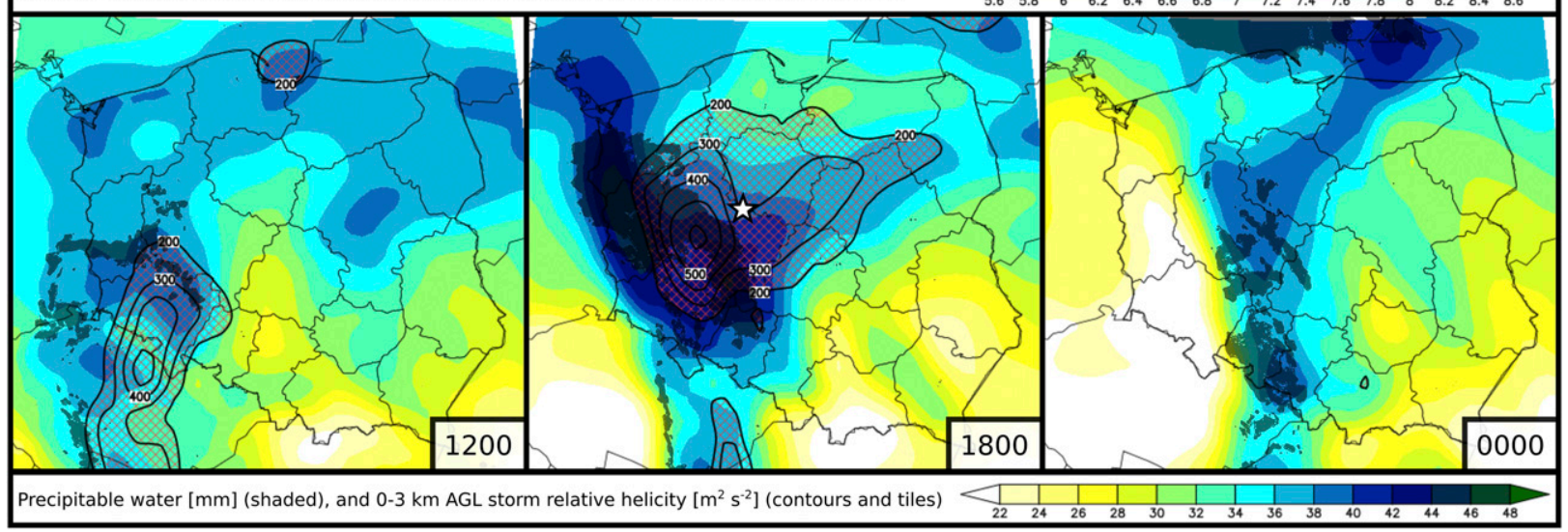

FIG. 4. (top) The 0-6-km wind shear (tiled contours) and MU CAPE (shaded). (middle) The 0-3-km wind shear (tiled contours) and 800-500-hPa temperature lapse rate (shaded). (bottom) The 0-3-km storm relative helicity (tiled contours) and precipitable water (shaded). Based on (left) 1200 UTC 11 Aug 2017, (center) 1800 UTC11 Aug 2017, and (right) 0000 UTC 12 Aug 2017 NCEP FNL analysis. Star symbol denotes location and hour for which model sounding is presented in Fig. 5. Transparent black polygons denote area of radar reflectivity higher than $25 \mathrm{dBZ}$ (derived from POLRAD network).

in defining convective mode (squall lines, bow echoes, mesoscale convective vortices) and diurnal cycle. Wandishin et al. $(2008,2010)$ estimated that with $0-24 \mathrm{~h}$ convective forecasts it was possible to successfully predict MCS in $70 \%$ of cases. By reducing the uncertainties associated with initial conditions (e.g., relative humidity, wind speed, instability) to below the observational uncertainty it was possible to increase
MCS prediction rate to $85 \%$. The importance of uncertainty in initial conditions on MCS prediction was also found in the studies of Kühnlein et al. (2014) and Lawson and Gallus (2016). Investigating the 8 May 2009 "Super Derecho" event Grunzke and Evans (2017) used WRF and the ensemble Kalman filter to examine predictability of the warm-core mesovortex embedded in MCS. Simulations successfully predicted 


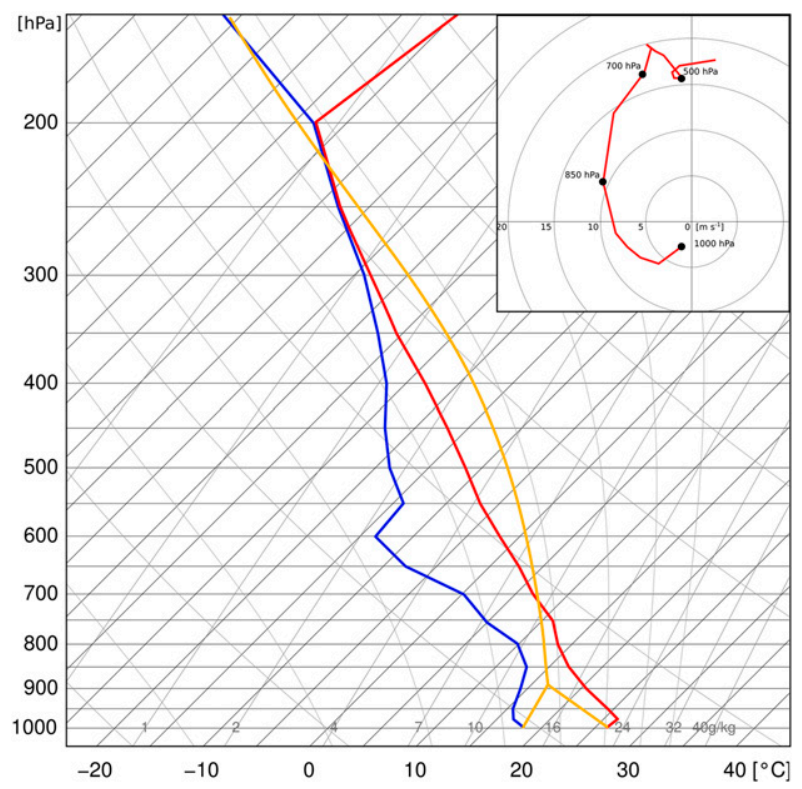

FIG. 5. Vertical profile of temperature (red line), dewpoint temperature (blue line), and wind (hodograph) for Gniezno $\left(52.5^{\circ} \mathrm{N}, 17.5^{\circ} \mathrm{E}\right)$ derived from NCEP FNL analysis for $1800 \mathrm{UTC}$ 11 Aug 2017. Orange line denotes most-unstable parcel. Profile indicates environment just ahead of the approaching convective line.

MCS in all members (50) but only in $14 \%$ did a mesovortex-like feature occurred.

\section{d. Aim of the study}

In Poland, an average of 10 bow echoes and 1 derecho are reported each year (Celiński-Mysław and Matuszko 2014; Celiński-Mysław and Palarz 2017). The derecho of 11 August 2017, which killed 6 people and caused a remarkable wind damage with surface winds exceeding $42 \mathrm{~m} \mathrm{~s}^{-1}$, turned out to be one of the strongest in the history of Poland. This study documents atmospheric conditions, development and evolution of the storm, and assesses the possibilities of its short-term prediction within high-resolution simulations based on the initial conditions preceding the event. The emphasis is on analyzing system morphology and highlighting the importance of a mesovortex in producing the most significant damage. We analyze the link between evolution of convection at early stages and accompanying environmental ingredients. An improved insight into the analyzed storm morphology may improve predictability of such events in Europe for the foreseeable future. While a powerful derecho would be normally linked to the area of the United States (Coniglio and Stensrud 2004; Ashley and Mote 2005; Guastini and Bosart 2016), the uniqueness of this study is that we document the occurrence of such an event in a region where they are not commonly observed.

\section{Dataset and methodology}

\section{a. Observational and NWP data}

For the purposes of a synoptic and mesoscale analysis, the National Centers for Environmental Prediction (NCEP) Global Forecast System (GFS) Final (FNL) gridded analysis datasets (resolution of $0.25^{\circ}$; NCEP/ NWS/NOAA/U.S. Department of Commerce 2015a) are used for 1200 and 1800 UTC 11 August and 0000 UTC 12 August 2017. FNL is very similar to the operationally running GFS (it has the same model formulation and assimilation techniques), but is slightly delayed and contains about $10 \%$ more observational data such as soundings or satellite data. Thanks to this, the FNL provides a more reliable estimate of actual conditions.

NCEP GFS FNL data is used to display multiple parameters. Baseline circulation patterns are identified for $500 \mathrm{hPa}, 850 \mathrm{hPa}$, and mean sea level pressure fields. Kinematic and thermodynamic conditions are assessed within the use of parameters that in the previous studies have been considered valuable for forecasting deep moist convection and well-organized MCSs (Doswell et al. 1996; Evans and Doswell 2001; Craven and Brooks 2004; Cohen et al. 2007; Coniglio et al. 2007, 2011; Weisman et al. 2013; Púčik et al. 2015; Taszarek et al. 2017; Celiński-Mysław et al. 2018). These include: mostunstable (MU) convective available potential energy (CAPE), 0-6 km above ground level (AGL) deep-layer shear (DLS), 0-3 km AGL midlevel shear (MLS), 800500-hPa vertical temperature lapse rate, $0-500 \mathrm{~m}$ AGL mixed-layer mixing ratio, and precipitable water.

Determination of synoptic conditions is also supported by the surface analysis charts from the Polish Institute of Meteorology and Water Management, surface synoptic observations (SYNOP reports), MSG (Meteosat Second Generation) geostationary satellite image, and radar data from the POLRAD network including reflectivity and radial velocity. POLRAD system consists of eight C-band Doppler radars: Meteor 500C (Poznań, Brzuchania, Świdwin), Meteor 1500C (Legionowo, Gdańsk), and dual-polarimetric Meteor 1600C (Pastewnik, Rzeszów, Ramża) of Selex SI Gematronik (in this study we use data from Pastewnik, Poznań and Gdańsk). POLRAD provides two full volume scans in two modes during the base period of 10 min: reflectivity scan in the range of $250 \mathrm{~km}$, lasting $4 \mathrm{~min}$ (1-km spatial resolution), and reflectivity and Doppler velocity scan in the range of $125 \mathrm{~km}$, lasting 6 min $(0.5-\mathrm{km}$ spatial resolution). Rainbow 5 software 
а)

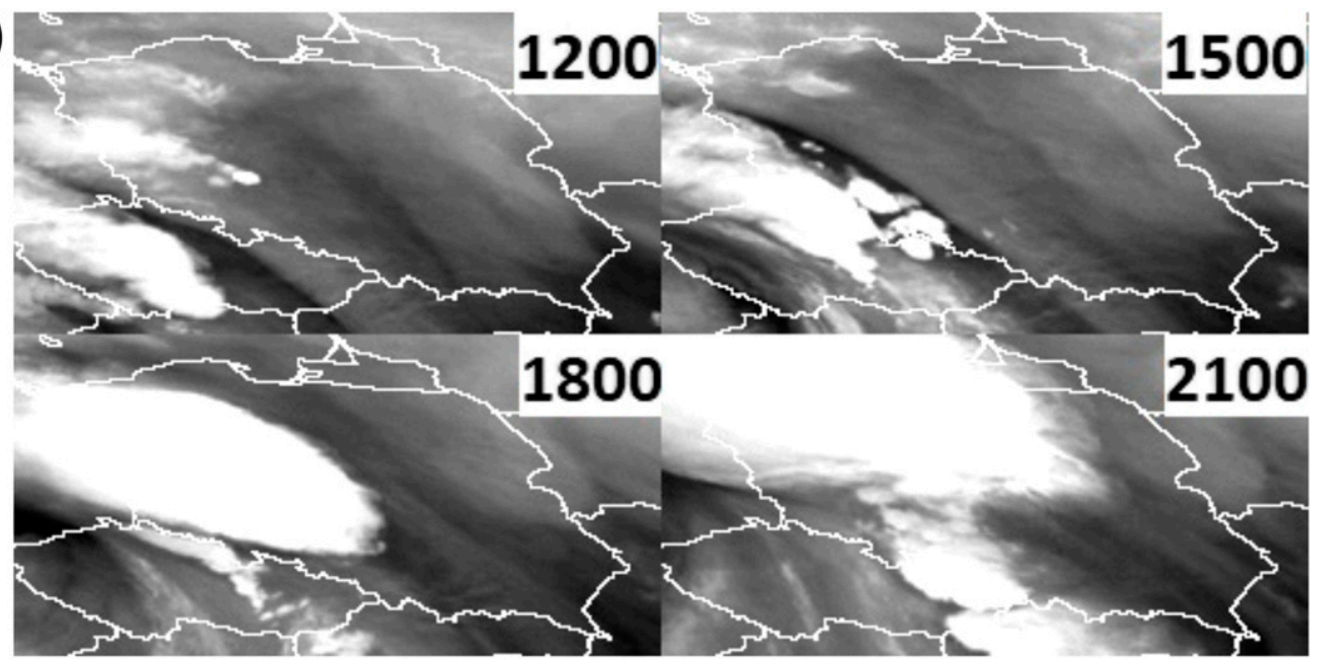

b)

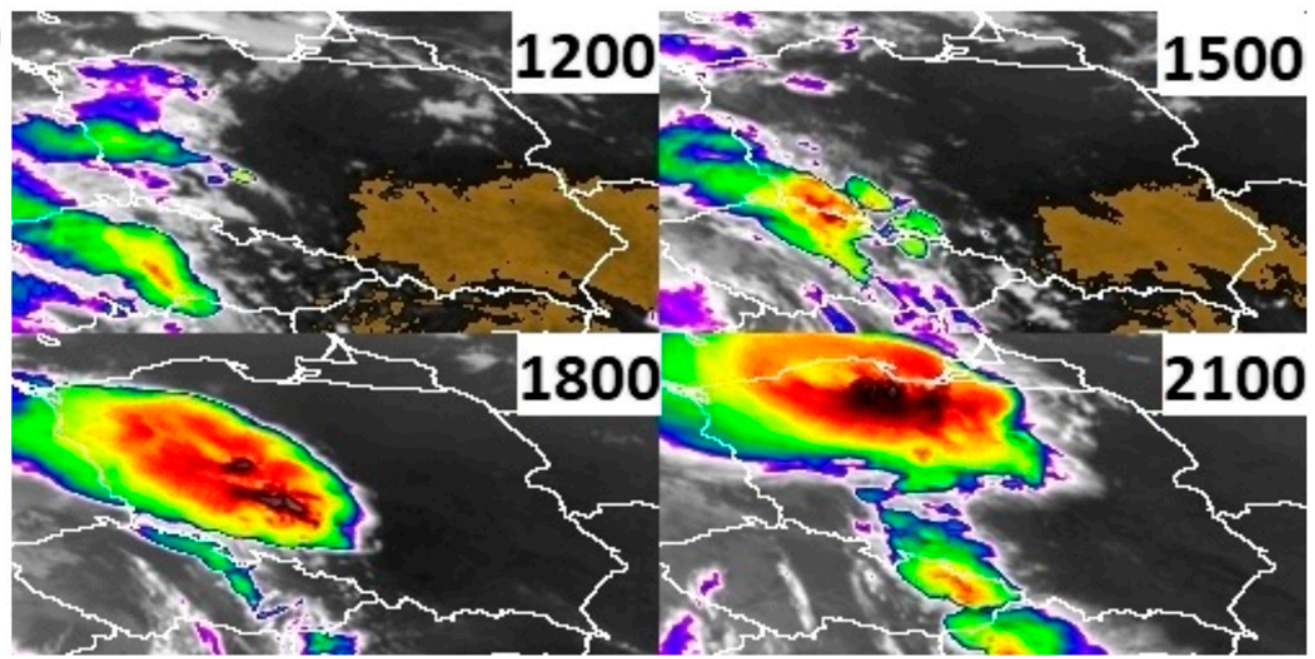

FIG. 6. Meteosat Second Generation (MSG) satellite image for 1200, 1500, 1800, and 2100 UTC 11 Aug 2017 in (a) water vapor channel, and (b) with cloud-top temperatures.
(Selex 2010) is used to generate radar products. Further details on the POLRAD network are available in Ośródka et al. (2014). The evolution of a derecho and evaluation of the damage track are investigated within the use of 1182 severe wind reports from ESWD, aerial images, and information on damage in the forest stand from Poland's Regional Directorate of State Forests.

\section{b. High-resolution WRF simulation}

WRF 3.9.1 within Unified Environmental Modeling System (UEMS) version 18 was applied to run highresolution, dynamically downscaled simulations. In our considerations, two one-way nested domains using ratio 1:3 are defined. The outer domain $(\mathrm{d} 01)$ is determined with a spatial resolution of $3.6 \mathrm{~km}(245 \times 224$ grid cells $)$, while the second $(\mathrm{d} 02)$ with $1.2 \mathrm{~km}(628 \times 601$ cells $)$. Domain d01 is centered on coordinates $51.826^{\circ} \mathrm{N}$, $19.313^{\circ} \mathrm{E}$, while $\mathrm{d} 02$ refers to the area of Poland. The vertical extent for two domains includes 45 levels up to $5 \mathrm{hPa}$. In the preprocessing stage, the model terrain MODIS with a resolution of $2 \mathrm{~min}$ and $30 \mathrm{~s}$ was applied respectively to $\mathrm{d} 01$ and $\mathrm{d} 02$. The model is configured using the Mercator projection.

As initial and lateral boundary conditions, two operationally running global models are used. These are GFS with a resolution of $0.25^{\circ}$ (NCEP/NWS/NOAA/U.S. Department of Commerce 2015b) and the European Centre for Medium-Range Weather Forecasts (ECMWF) with a resolution of $0.125^{\circ}$. Configuration of physical parameterization refers to studies of MCS modeling (Weisman et al. 2008) and severe thunderstorms in Poland (Taszarek et al. 2016; Pilguj et al. 2019). For planetary boundary layer description, the Yonsei University scheme (Hong et al. 2006) is used. For shortwave and longwave radiation 


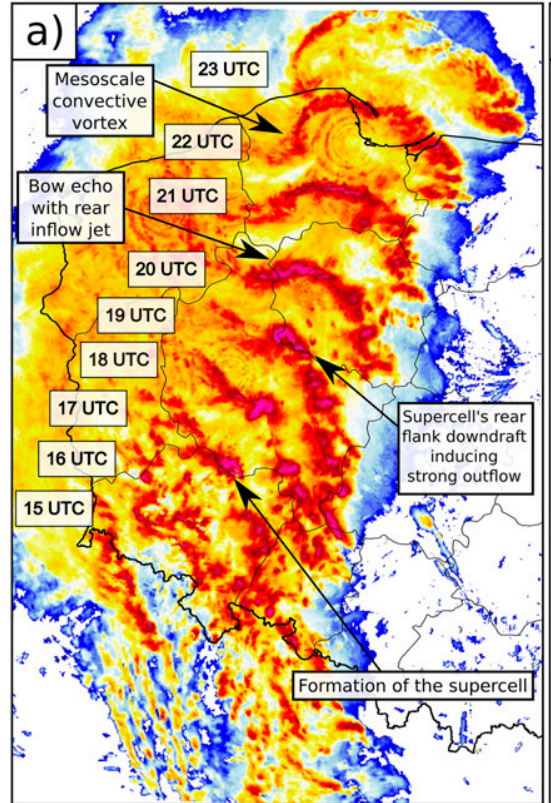

Maximum reflectivity with 1-hour steps

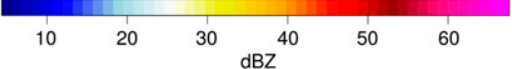

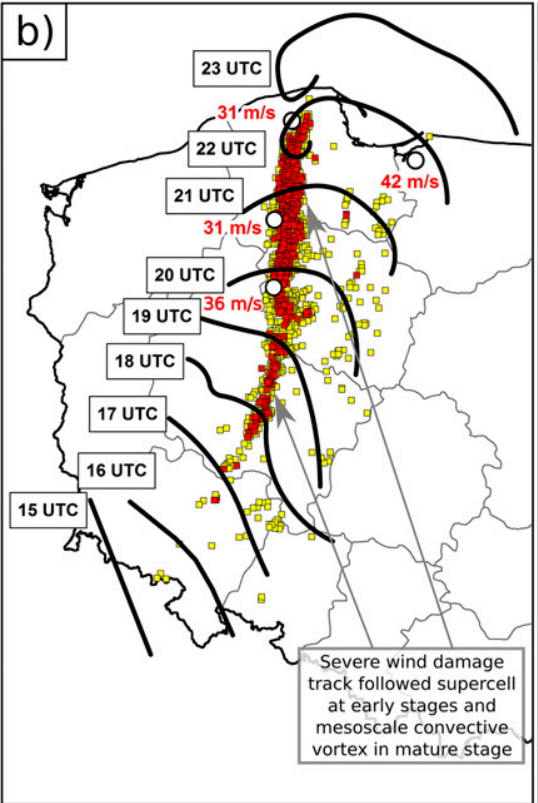

Severe wind reports

F0 damage $\square$ F1 damage

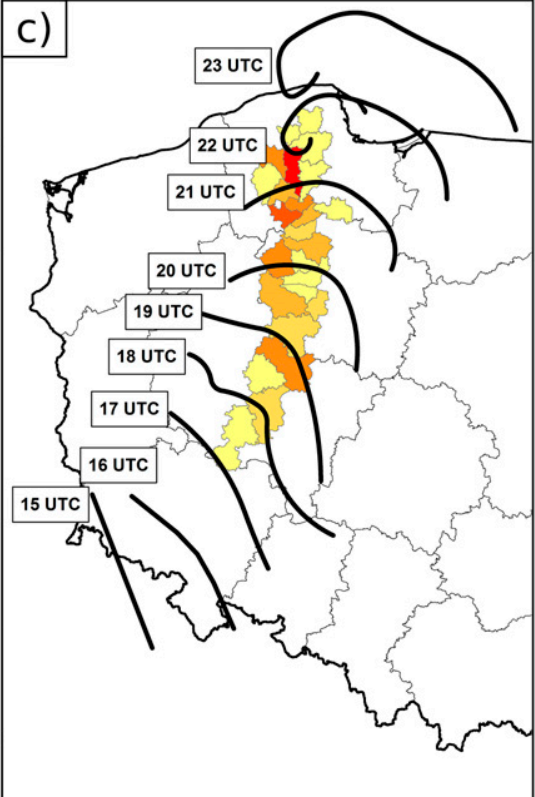

Volume of damaged trees $\left(\mathrm{m}^{3} \times 1000\right)$

$\square$ 15- $100 \quad \square$ 250-500 $\square$ 1000-2000
$\square 100-250 \quad \square 500-1000 \quad \square$ 2000-2500

FIG. 7. (a) Maximum reflectivity with 1-h steps (source: POLRAD network). (b) Severe wind gust reports (yellow squares: F0 damage, red squares: F1 damage, white circles: peak wind gusts exceeding $25 \mathrm{~m} \mathrm{~s}^{-1}$ registered at surface synoptic stations), and position of the convective line (black line) with 1-h steps. (c) Volume of damaged trees in counties (based on data from Poland's Regional Directorate of State Forests) and position of the convective line (black line) with 1-h steps.

representation, the Community Atmosphere Model version 3 (CAM3) radiation scheme (Boville et al. 2006) is applied. In prepared simulations, microphysical processes are described by WRF single-moment 6-class scheme (WSM6; Hong and Lim 2006). Because of simulations with a high-resolution grid, no cumulus parameterization is used. For representing land surface physics, the Noah land surface model is applied. Simulations work with time step of $16 \mathrm{~s}$ for the outer domain and $5.3 \mathrm{~s}$ for the inner one. In further considerations, only results from the inner domain (d02) were used.

Simulations were performed within the initial conditions from 0000, 0600, and 1200 UTC 11 August 2017, derived from both GFS and ECMWF (analysis phase). In total, six simulations were prepared, where (despite different hours of model initiation) each one was completed at 0000 UTC 12 August 2017. With the chosen initial conditions, we investigate whether it would be possible to successfully predict MCS with a potential for damaging wind gusts. Our main focus is on investigating storm morphology, position and timing of the system (simulated maximum reflectivity), estimated strength (simulated peak wind gusts), and the possibility of mesocyclones (simulated 2$5 \mathrm{~km}$ AGL updraft helicity tracks; Kain et al. 2008). Threedimensional visualization techniques are also applied within the use of the VAPOR tool (Clyne et al. 2007) to display a cross section through a bow echo apex.

\section{Event analysis}

\section{a. Evolution of synoptic conditions prior to the evening of 11 August 2017}

In the second week of August 2017, a long-wave trough was situated over the western parts of Europe, while ridge stretched from central parts of the Mediterranean Sea to western Russia. As a result, a warm and unstable subtropical air moved toward central Europe, spreading mainly over Poland, Austria, Czech Republic, Hungary, and Slovakia. A wavy frontal boundary stretched in the corridor from the Gulf of Genoa to Lithuania. During the night of 10-11 August, MCS passed through Austria, Czech Republic, and southwestern Poland and left postconvective cloudiness, which maintained until afternoon of 11 August (Fig. 1). At 1200 UTC, a shallow surface low was located over northwestern Poland while an eastwardly moving cutoff low was placed over the western Alps (Fig. 1). A jet stream extended from the central Mediterranean up to the German-Polish border where an upper-level divergence and synoptic-scale lift took place. 


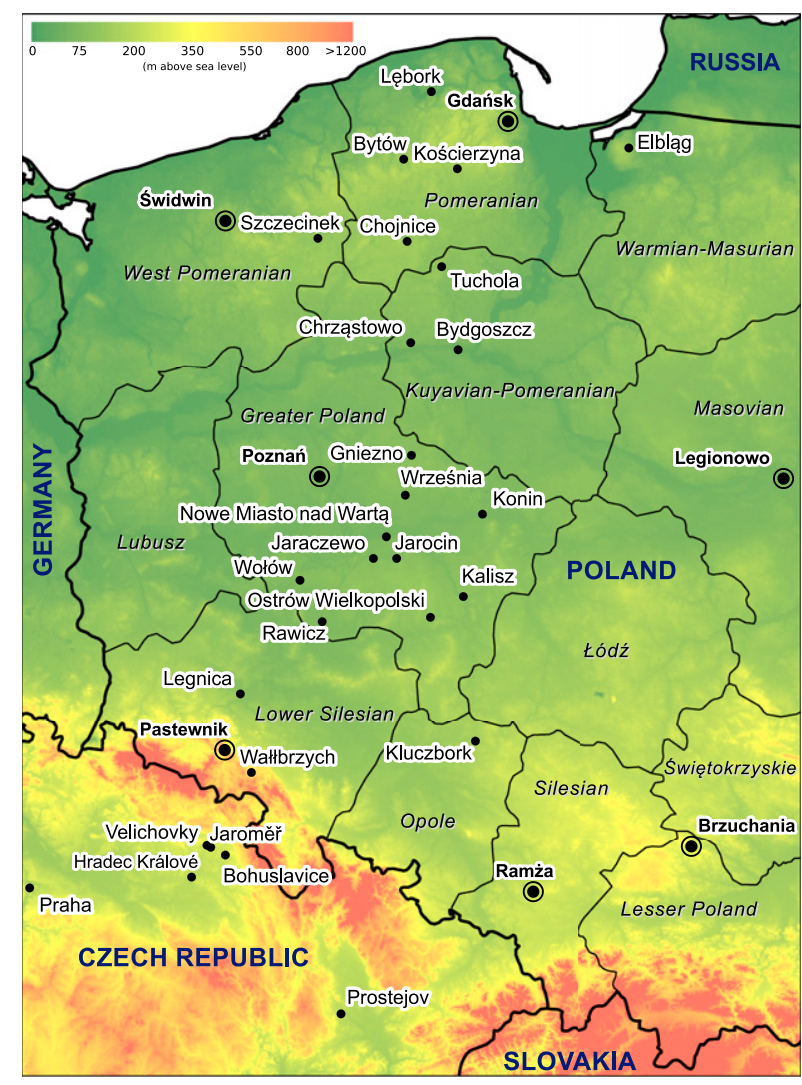

FIG. 8. Hypsometric map of Poland with polish voivodeships and locations mentioned in section 3. Large black points indicate location of meteorological radars.

\section{b. Mesoscale conditions in the evening of 11 August 2017}

At 1200 UTC, Poland was under the influence of a warm $\left(20^{\circ} \mathrm{C}\right.$ at $\left.850 \mathrm{hPa}\right)$ and humid (mixing ratio: 10 $12 \mathrm{~g} \mathrm{~kg}^{-1}$ ) subtropical air mass advection. However, frontal and convective cloudiness, which occurred over western parts of the country in the morning and afternoon hours (Fig. 1), significantly limited insolation and diurnal increase in the temperature. Further to the east in the cloudless area, a strong diurnal heating (maximum temperatures above $30^{\circ} \mathrm{C}$ ) took place (Fig. 2). The frontal boundary stretched from the central Czech Republic to northwestern Poland, and a $10-15 \mathrm{~m} \mathrm{~s}^{-1}$ southerly flow dominated at $500 \mathrm{hPa}$ (Fig. 3). Weak elevated storms remained in southwestern Poland, while a shallow surface low entered south-central Poland and convergence line started to form on its western flank near the Polish-Czech border. Moisture pooling together with increasing temperature lapse rates in the midtroposphere $\left(>7 \mathrm{~K} \mathrm{~km}^{-1}\right)$ started to build up a moderate to high thermodynamic instability over the central and eastern parts of Poland (Fig. 4). Sounding
TABLE 1. Timeline of the most important events in MCS evolution.

\begin{tabular}{cc}
\hline \hline Time & \multicolumn{1}{c}{ Description } \\
\hline 1500-1600 UTC & $\begin{array}{c}\text { Development of the convective cells } \\
\text { on the Polish-Czech border. } \\
\text { Development of a supercell in } \\
\text { southwestern Poland. } \\
\text { Upscale growth of the MCS. Supercell } \\
\text { produces swath of significant wind } \\
\text { damage. } \\
\text { 1700-1900 UTC } \\
\text { RIJ descends on the eastern flank } \\
\text { of the supercell and develops a } \\
\text { bow echo. } \\
\text { Supercell evolves into a bookend } \\
\text { vortex and later into a comma echo } \\
\text { with embedded MCV. Bow echo } \\
\text { continues to expand within the } \\
\text { support of an RIJ. Swath of } \\
\text { damaging winds follows MCV and } \\
\text { its eastern flank. } \\
\text { MCS starts to weaken and moves } \\
\text { offshore. }\end{array}$ \\
\hline
\end{tabular}

measurement taken in Legionowo near Warsaw at 1200 UTC (central-eastern Poland) indicated MU CAPE of $2900 \mathrm{~J} \mathrm{~kg}^{-1}$. DLS exceeding $20 \mathrm{~m} \mathrm{~s}^{-1}$ was located over southwestern Poland on the peripheries of the jet stream. A southerly flow at $700 \mathrm{hPa}$ with opposing surface winds also provided a broad area of MLS exceeding $15 \mathrm{~m} \mathrm{~s}^{-1}$ (Fig. 4). Such values are known to be conducive to the development of linear MCSs capable of producing damaging wind gusts when combined with sufficient thermodynamic instability (Doswell and Evans 2003; Cohen et al. 2007; Weisman et al. 2013; Celiński-Mysław et al. 2018). Similar estimates of a wind shear have been confirmed by sounding measurements taken at 1200 UTC in Prague and Prostejov in the Czech Republic (airflow of $20-25 \mathrm{~m} \mathrm{~s}^{-1}$ at $700-500 \mathrm{hPa}$ ).

The synoptic-scale lift, moisture convergence and orographic lift led to a widespread convective initiation on the border between the Czech Republic and Poland at around 1400-1500 UTC (Fig. 2). At 1500 UTC, measurements from the synoptic stations ahead of the approaching convergence line indicated temperatures above $30^{\circ} \mathrm{C}$ and dewpoints exceeding $18^{\circ} \mathrm{C}$ (locally $20^{\circ} \mathrm{C}$; Fig. 2), which contributed to an increase in the thermodynamic instability. A surface low was located on the Czech-Slovak-Polish border before it moved northward. In the next hours, convective cells within the support of a strong vertical wind shear started to group into a linear structure (Fig. 2). At this time, a change in the trajectory of the system from northeast to northnortheast can be observed.

At 1800 UTC, the surface low was centered over south-central Poland while the well-developed convergence line with an impressive $12-14 \mathrm{~g} \mathrm{~kg}^{-1}$ mixing ratio 


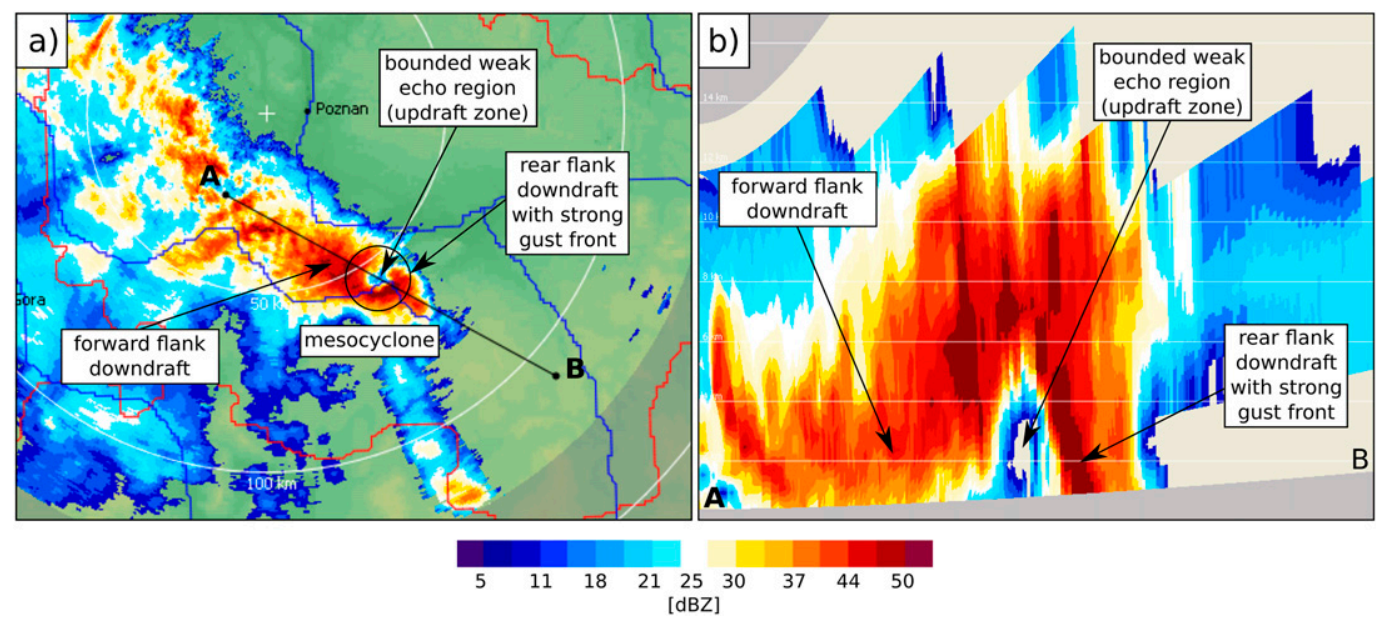

FIG. 9. Reflectivity at $4 \mathrm{~km}$ above radar height and cross section of the supercell southeast of Poznań at 1743 UTC; derived from meteorological radar in Poznań.

and 40-46-mm precipitable water was placed on its western flank (Fig. 4). Simultaneously, the line was pushed toward the northeast by a midlevel jet stream. This combination provided strong vertical wind shear and veering wind profiles $(0-3-\mathrm{km}$ storm with relative helicity ranging from 200 to $600 \mathrm{~m}^{2} \mathrm{~s}^{-2}$; Fig. 4). As indicated in the analysis of the radar data (discussed in detail in a later part of the paper), one of the cells embedded in the line was a supercell (mesocyclone) that formed at around 1700 UTC in southwestern Poland. In the next hours, the aforementioned supercell evolved into a bookend vortex and later into an MCV (discussed in detail in a further part of the paper). A model FNL sounding from 1800 UTC displaying the environment just ahead of the approaching convergence line $\left(52.5^{\circ} \mathrm{N}\right.$, $17.5^{\circ} \mathrm{E}$ ) indicated a well-developed clockwise-curved hodograph with northeasterly inflow and $1500 \mathrm{~J} \mathrm{~kg}^{-1}$ of MU CAPE (Fig. 5). Such profiles are known to be conducive to supercells and extremely severe thunderstorms (Brooks and Wilhelmson 1993; Bunkers et al. 2000; Weisman and Rotunno 2000).

As indicated by the FNL analysis field, at 1800 UTC the overlap between the vertical wind shear and thermodynamic instability in the eastern part of the line was the most prominent. MU CAPE was up at around $2500 \mathrm{~J} \mathrm{~kg}^{-1}$ while MLS exceeded a high value of $20 \mathrm{~m} \mathrm{~s}^{-1}$ (Fig. 4). At this point, MCS was in the mature stage and updrafts were well organized. The MSG image for 1500 and 1800 UTC indicated an upscale growth for the convection with multiple overshooting tops (Fig. 6). The system progressed toward the northeast along the zone of an increased horizontal pressure $\left[\sim 8.5 \mathrm{hPa}(100 \mathrm{~km})^{-1}\right]$, temperature $\left[\sim 9^{\circ} \mathrm{C}(100 \mathrm{~km})^{-1}\right]$, and dewpoint $\left[\sim 5^{\circ} \mathrm{C}\right.$ $(100 \mathrm{~km})^{-1}$ ] gradients (Fig. 2). As evidenced in previous studies, such gradients can be conducive to the creation of a mesocyclone vorticity (Maddox et al. 1980; Markowski et al. 1998; Rasmussen and Blanchard 1998; Rasmussen et al. 2000). From 1800 UTC, a characteristic bowing of the line as a result of the descending RIJ was observed (Fig. 7). The western flank of the line was the place wherein a supercell that was initially embedded evolved into a bookend vortex and later into an MCV (discussed in a further part of the paper). Examination of the synoptic data indicates that at 2100 UTC air pressure was raised in the Szczecinek and Chojnice stations (north-central Poland), and a local high occurred as a result of a strong downdraft accompanying the MCV. In the late evening and nighttime hours, thermodynamic instability significantly dropped and storms became elevated. After moving offshore, the MCS started to weaken.

\section{c. Damage track and radar data analysis}

The derecho of 11 August 2017 caused widespread damage in the area extending from Hradec Kralove Region in the Czech Republic through Lower Silesia, Greater Poland, to Kuyavian-Pomeranian and Pomeranian Voivodeships in Poland (Figs. 7b and 8). In total, 1182 wind reports within this system were inserted into the ESWD. The most considerable damage reaching an intensity of up to F1 in the Fujita scale (Fujita 1971) was reported in southern and eastern Greater Poland Voivodeship, western Kuyavian-Pomeranian Voivodeship, as well as southern and central parts of Pomeranian Voivodeship. The storm system destroyed around 39200 ha of forests and partially damaged another 40500 ha. According to estimates by Poland's Regional Directorate of State Forests, approximately 20 million of trees ( 9.8 million $\mathrm{m}^{3}$ of wood) were affected by the strong winds. The MCS also damaged roughly 20000 buildings and cut off power to around 500000 customers. 

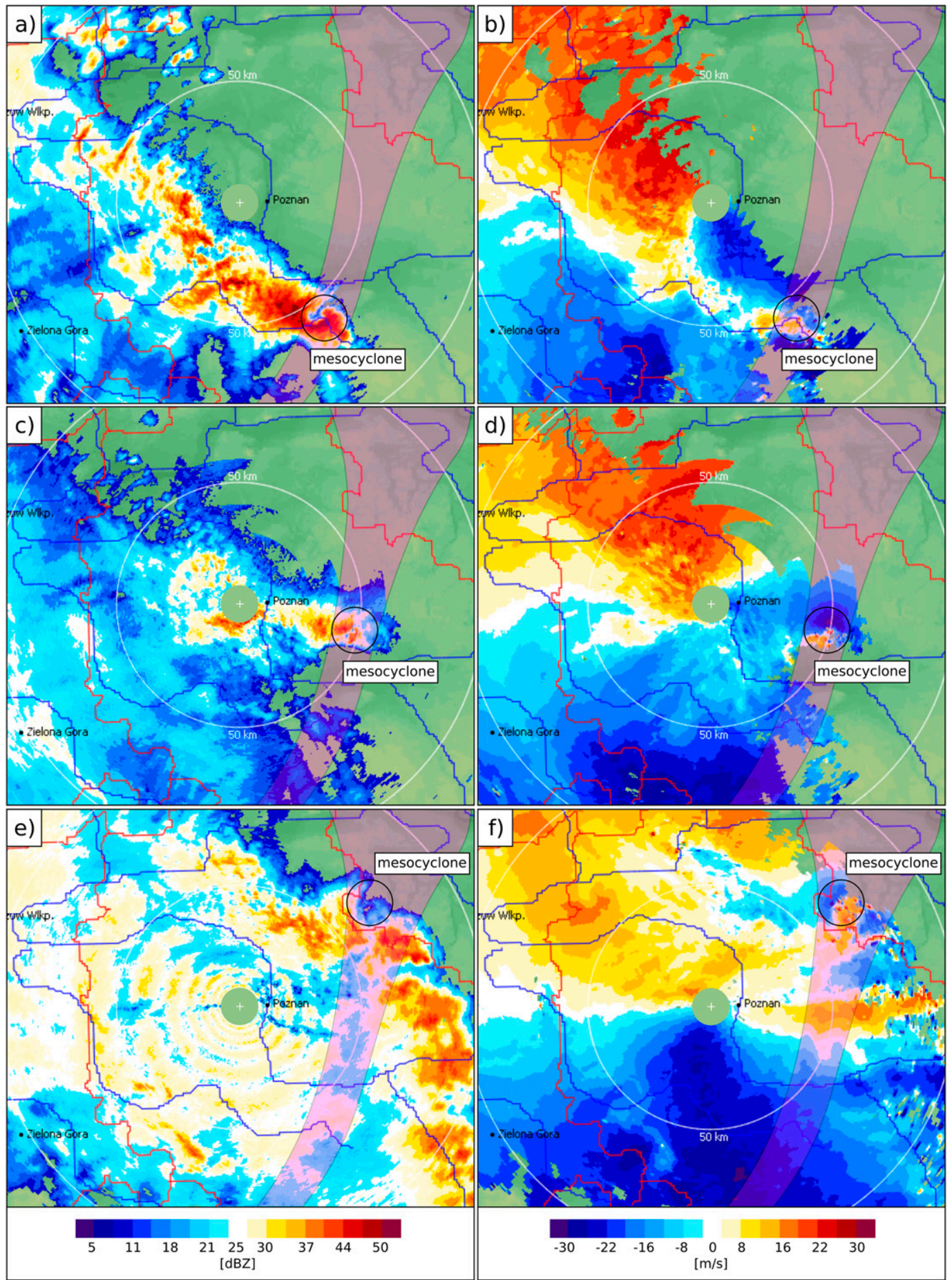

FIG. 10. (left) Reflectivity and (right) radial velocity at $4 \mathrm{~km}$ above radar height at (a),(b) 1743, (c),(d) 1813, and (e),(f) 1903 UTC; derived from meteorological radar in Poznań. Bright pink polygon indicates severe wind damage track as indicated in Fig. 7. Please note that the signal is interrupted from 1800 UTC when heavy rain passes through the radar site. 
Moreover, 6 people lost their lives and another 58 were injured in that event. In Table 1, we provide a timeline of the most important phases associated with the evolution of the MCS. These phases are described in the following paragraphs. Hypsometric map of Poland with locations mentioned in the text are displayed in Fig. 8.

The first phase starts with the damage path in the northern Czech Republic, near Jaroměr. The weather station in Velichovki, belonging to the Czech Hydrometeorological Institute (CHMI), measured a peak wind gust of $27.9 \mathrm{~m} \mathrm{~s}^{-1}$ at 1520 UTC. Severe wind gusts also caused significant damage to buildings and trees in Bohuslavice, near Nové Město nad Metují. After passing over the Sudetes Mountains, the storms temporarily weakened and caused minor wind damage and flash floods in the area between Wałbrzych and Wołów (southwestern Poland). At this time, radar data obtained through the CZRAD radar network suggested a right-moving supercell embedded in the convective line over the Czech-Polish border. The track of this supercell overlapped with the damage path in northern parts of the Czech Republic and Wałbrzych region (southwestern Poland). Further, the cell probably has undergone cyclic evolution (Adlerman et al. 1999) and strengthen between Legnica and Wołów at around 1600-1700 UTC (Fig. 7). Unfortunately, the lack of radar data from this area, caused by a failure of the Pastewnik radar (southwestern Poland), makes a direct distinction between cyclic evolution or two seperate supercells impossible.

After the convective line entered Poland, it started to build up from the east and take advantage of the unstable warm and moist air mass (Figs. 4 and 7). The whole system began to quickly grow and intensify. At this point, a few large hail and severe wind gust events were reported on the southeastern edge of the MCS. At around 1700 UTC, a dominant supercell, which developed between Legnica and Wołów, moved to the area of Rawicz (Fig. 8), producing large hail of up to $5.5 \mathrm{~cm}$ and damaging wind gusts. A vertical cross section of radar reflectivity from the Poznań radar at 1743 UTC (Fig. 9) indicated classical supercell components (a subjective analysis based on radar scans) such as rear flank downdraft (RFD), forward flank downdraft, and a bounded weak echo region on the leading edge of the cell (Doswell and Burgess 1993). In addition, a velocity couplet was observed in the low and midtroposphere (Fig. 10).

At around 1800 UTC, the convective line stretched from Poznań, to Jarocin, Ostrów Wielkopolski, and Kluczbork. The supercell moved from Rawicz to Jarocin area, and caused considerable damage to buildings and forest, especially in Jaraczewo and Nowe Miasto

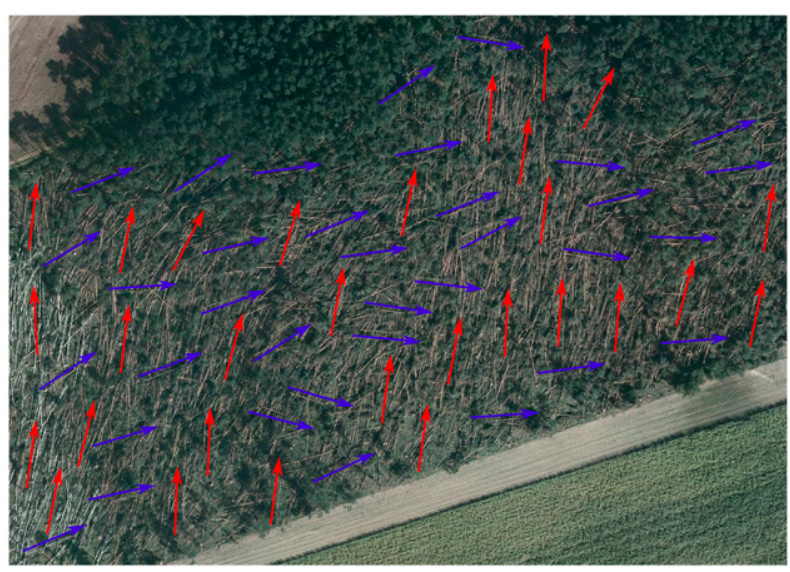

FIG. 11. Aerial photography with aftermath of the severe convective wind gust at around 1845 UTC near the village of Pawłowo $\left(52^{\circ} 29^{\prime} 06.1^{\prime \prime} \mathrm{N}, 17^{\circ} 31^{\prime} 44.3^{\prime \prime} \mathrm{E}\right)$. Arrows indicate direction of felled trees due to gust front (red) and rear flank downdraft associated with the mesocyclone (blue), based on subjective analysis.

nad Wartą (Fig. 8). At 1813 UTC, a strong velocity couplet was indicated near Września on the Poznan radar. At around 1830 UTC, a peak wind gust of $34 \mathrm{~m} \mathrm{~s}^{-1}$ was measured in Gniezno. At that time, the southeastern part of the convective line stretched between Kluczbork and Konin area, and then moved in a roughly parallel manner (Fig. 7). A comparison with severe weather reports revealed that swaths of the most significant wind damage followed a mesocyclone (Figs. 7 and 10). The maximum width of the damage path in this area was equal to a size of about $20-25 \mathrm{~km}$. Most of the trees were turned into the north and northeast, but locally some of them were also arranged into the east and southeast (Fig. 11). This may suggest that in addition to the powerful wind on the leading edge of the line, RFD associated with the mesocyclone might have also played an important role in contributing to wind damage.

Beginning at 1900 UTC, a mesocyclone started to transform itself into an accelerating bowing segment of the convective line, indicating intrusion of RIJ (Fig. 12). From this time, the damage path started to expand. At 1913 UTC, a strong velocity couplet was still visible from the radar in Poznan (around $75 \mathrm{~km}$ from the radar), although it is worth highlighting that after the storms passed over the radar site, the signal was disturbed by heavy rainfall (Figs. 10 and 12). Further radar scans $(1923,1933,1943$ UTC) revealed a strong gust front developing on the eastern flank of the mesocyclone (Fig. 12). At 1950 UTC a peak wind gust of $36 \mathrm{~m} \mathrm{~s}^{-1}$ was reported in Chrzastowo meteorological station. In the next radar scans, a characteristic rear inflow notch and a large bow echo can be observed. 

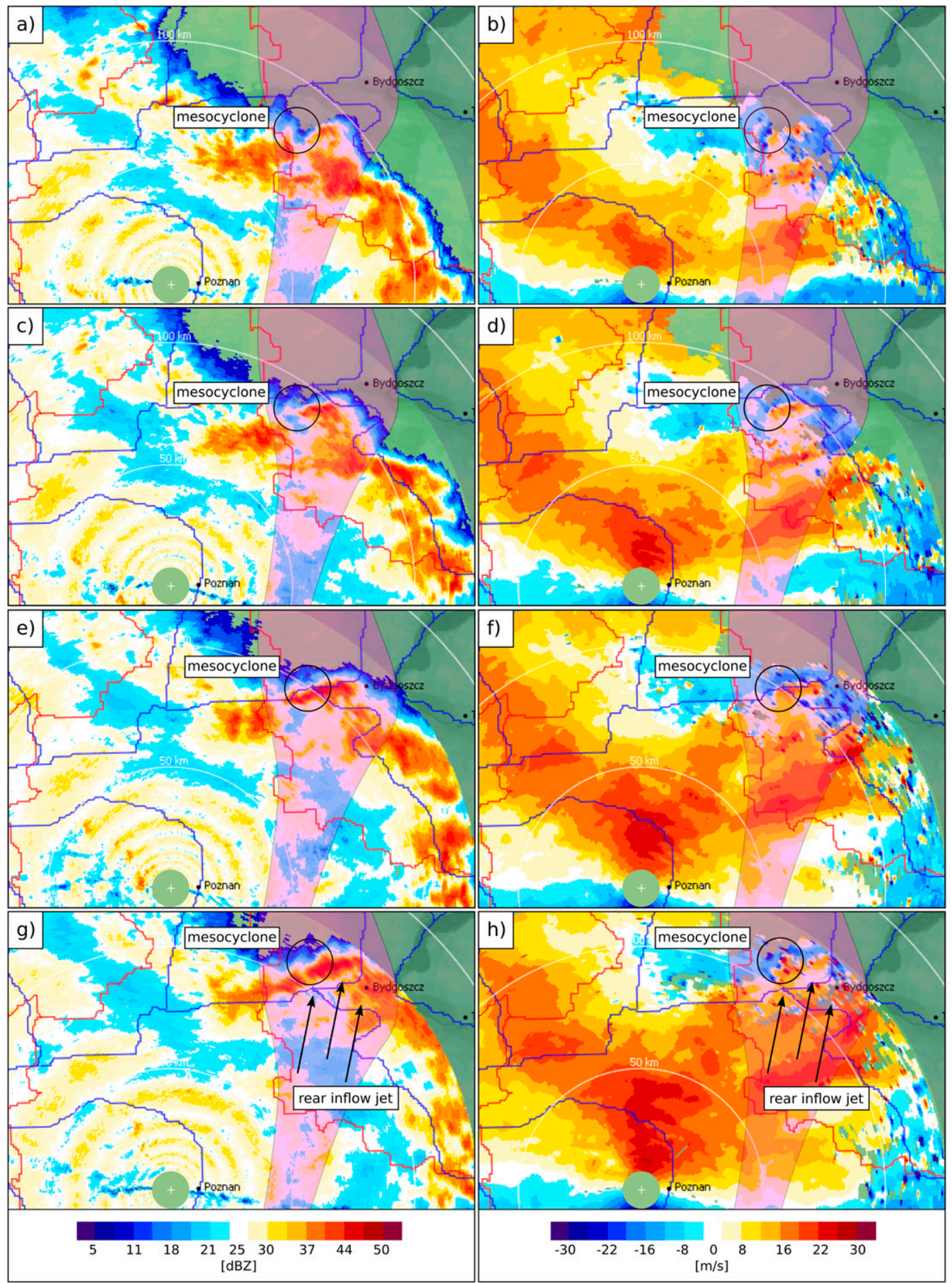

FIG. 12. (left) Reflectivity and (right) radial velocity at $4 \mathrm{~km}$ above radar height at (a),(b) 1923, (c),(d) 1933, (e),(f) 1943, and (g),(h) 1953 UTC; derived from meteorological radar in Poznań. Bright pink polygon indicates severe wind damage track as indicated in Fig. 7.

It may be possible that a mesocyclone enabled RIJ to descend to the surface and interact with RFD, similar as in the case studied by French and Parker (2014). From this time, a rapid acceleration of the system takes place and significant wind damage is reported in the forest in western Kuyavian-Pomeranian Voivodeship (Figs. 7 and 8). The western part of the line following the mesocyclone and its eastern flank produces a 

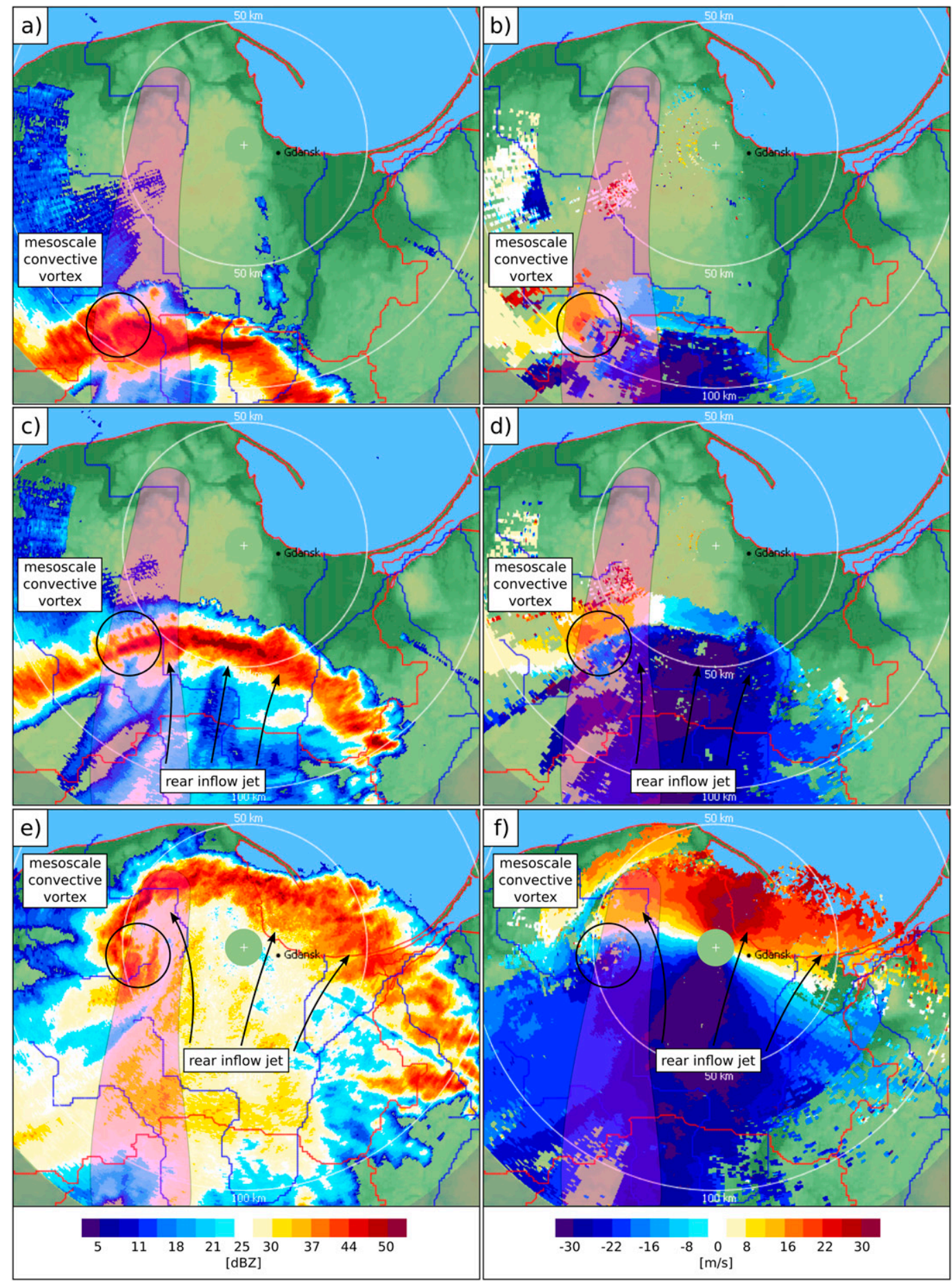

FIG. 13. (left) Reflectivity and (right) radial velocity at $2 \mathrm{~km}$ above radar height at (a),(b) 2034, (c),(d) 2104, and (e),(f) 2154 UTC; derived from meteorological radar in Gdańsk. Bright pink polygon indicates severe wind damage track as indicated in Fig. 7.

continuous swath of significant damage for the next few hours. Simultaneously, with a bow echo development, the southern part of the squall line transforms into a broken line (Bluestein and Jain 1985). A left-moving supercell at the end of that formation produces a large hail in the area of Kalisz city at around 2100 UTC.

Despite the difficulties in radar interpretation (at around 2000 UTC, the system was halfway between 
radar sites in Poznań and Gdańsk with a distance to each of more than $100 \mathrm{~km}$ ), we suppose that after passing Bydgoszcz, the mesocyclone evolved into a bookend vortex and, pushed by the strong RIJ at around 2100 UTC, turned into a comma echo with an embedded MCV (Fig. 13). A broad velocity couplet was observed by the radar in Gdańsk from 2030 to 2200 UTC. In the southern part of the $\mathrm{MCV}$, high radial velocities (of more than $30 \mathrm{~m} \mathrm{~s}^{-1}$ ) were observed. The majority of trees in this area were downed in the northeastern direction. Wind gusts of extreme intensity destroyed a significant part of the Tuchola Forest, including around 8000 ha of forest in the Rytel Forest District and 6000 ha of forest in the Lipusz Forest District (Figs. 7 and 14). According to the accounts of some witnesses, the entire forest sections in the area of Tuchola, Chojnice, Bytów, Kościerzyna, and Lębork (Fig. 8) were swept away within a few minutes. The timing of the wind reports and their location indicate that the most significant winds occurred after the bow echo passed, that is, exclusively within the MCV and its eastern flank (Figs. 7 and 13). It is plausible that interaction of MCV and RIJ might have induced surface winds of such intensity. Before the MCS moved offshore and entered the Gdańsk area, the meteorological station in Elblag recorded a peak wind gust of $42 \mathrm{~m} \mathrm{~s}^{-1}$, while the station in Lębork had $31 \mathrm{~m} \mathrm{~s}^{-1}$. Radar animation of the entire MCS life cycle is available in the online supplemental material.

\section{High-resolution simulation}

In this section, we assess whether it was possible to predict the studied MCS, given its location, intensity and storm morphology. For this purpose, we take into account the initial conditions from 0000, 0600 and 1200 UTC 11 August 2017, which indicate a hypothetical lead time (a true lead time would also include a lag for obtaining initial conditions and processing the data) of 15,9 , and $3 \mathrm{~h}$, respectively (taking into account the initiation of the first convective cells on the Polish-Czech border at around 1500 UTC). Earlier initialization times were also tested, but no satisfactory results were obtained. The initial conditions are derived from the GFS and ECMWF global models that are commonly used by weather forecasters in Poland. Simulation within the convection-permitting resolution makes it possible to more reliably reproduce the processes that take place during the evolution of the MCS.

Starting with simulations based on 0000 UTC (15-h lead time), both GFS and ECMWF indicated a proper area of convective initiation in southwestern Poland (Fig. 15), with ECMWF highlighting a potential for one dominant supercell (Fig. 16). In the later stages of the simulation, MCS in both scenarios evolves into a linear
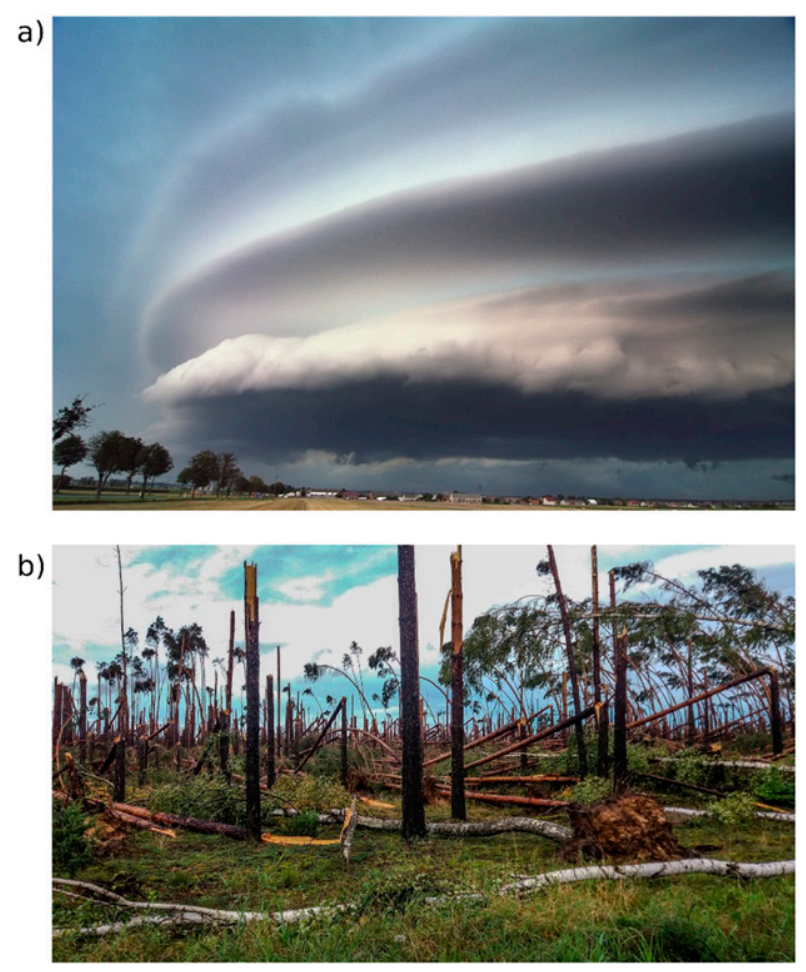

FIG. 14. (a) Shelf cloud observed at around 1730 UTC on the leading edge of the gust front produced by the supercell near the town of Krotoszyn $\left(51^{\circ} 44^{\prime} 27.2^{\prime \prime} \mathrm{N}, 17^{\circ} 26^{\prime} 21.7^{\prime \prime} \mathrm{E}\right)$. Photography: M. Taszarek. (b) Aftermath of the severe convective wind gust at around 2100 UTC near the village of Rozwalewo $\left(54^{\circ} 01^{\prime} 25.3^{\prime \prime} \mathrm{N}\right.$, $17^{\circ} 39^{\prime} 36.3^{\prime \prime}$ E). Photography: G. Zawiślak.

feature and moves toward northwestern Poland faster compared to the observations. The estimated $10 \mathrm{~m}$ AGL peak wind gusts are much higher in the ECMWF scenario and exceeds $40 \mathrm{~m} \mathrm{~s}^{-1}$, pointing to a risk for MCS with widespread damaging winds (Fig. 17). Interestingly, this scenario takes into consideration the damaging wind developing on the eastern flank of the simulated supercell, similar to the real course of events but shifted toward the west. The GFS scenario indicated much weaker wind potential enhancing $10 \mathrm{~m}$ AGL peak wind gusts of up to $25-30 \mathrm{~m} \mathrm{~s}^{-1}$ in the late stage of the system (Fig. 17). Both GFS and ECMWF scenarios simulated MCS too far to the west at this time, most likely due to underestimated cloud cover in a preconvective environment over western Poland (Figs. 1 and 18).

The initial conditions from 0600 UTC (9-h lead time to convective initiation) simulated a correct propagation of the system toward unstable air mass to the east (Fig. 4). The simulated initiation in the early stages as well as the location and morphology of the MCS were closer to the observations according to the GFS scenario (Fig. 15). The ECMWF-based simulation was more aggressive with a widespread convective initiation, a 


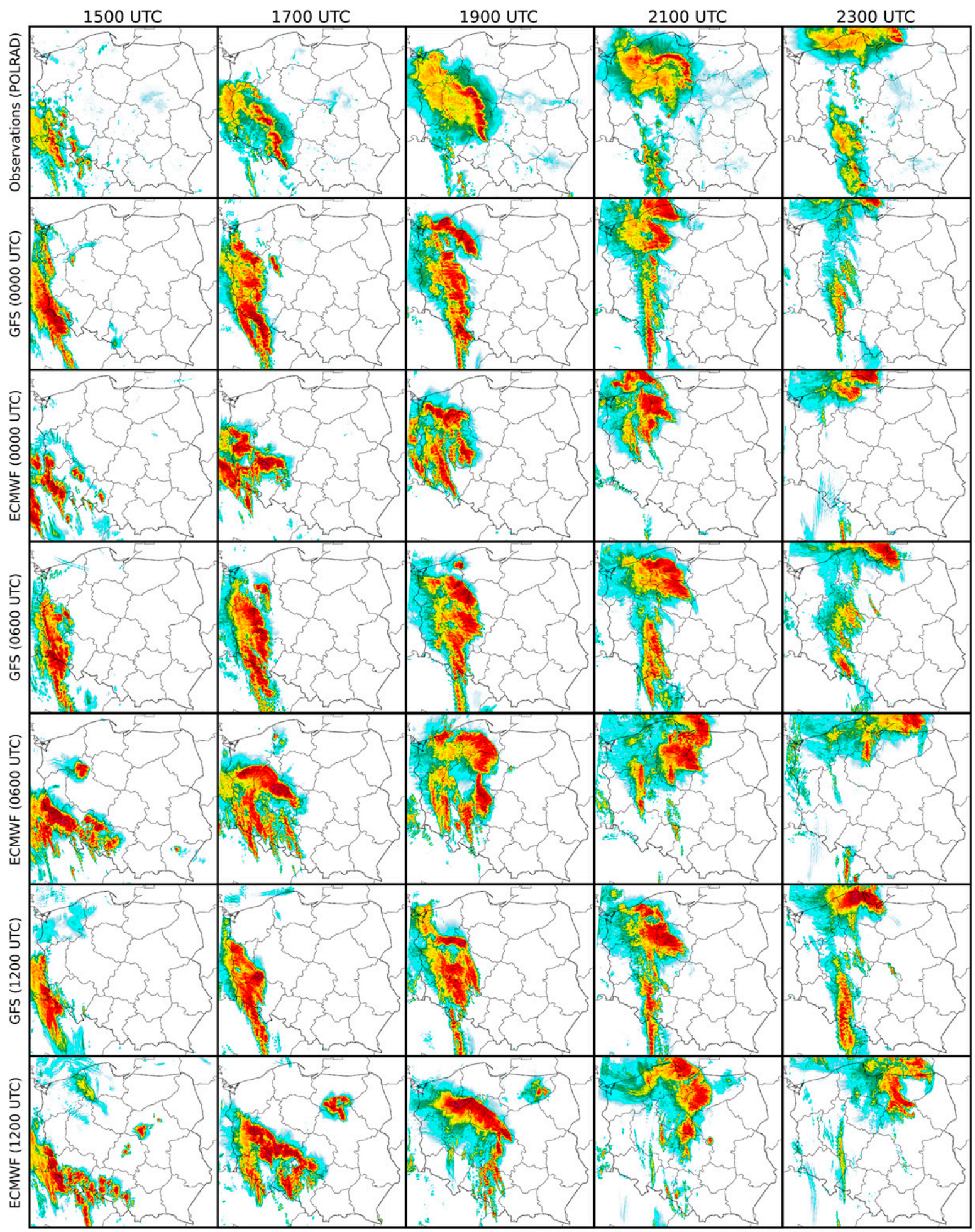

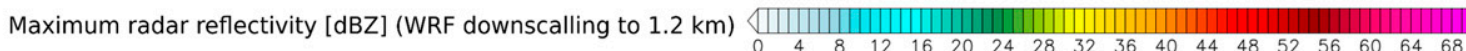

FIG. 15. Observed (POLRAD network) and simulated maximum reflectivity from WRF downscaling simulation to $1.2-\mathrm{km}$ grid for (from left to right) 1500, 1700, 1900, 2100, and 2300 UTC within initial conditions of: (rows 2 and 3 ) GFS and ECMWF 0000 UTC, (rows 4 and 5) GFS and ECMWF 0600 UTC, and (rows 6 and 7) GFS and ECMWF 1200 UTC 11 Aug 2017. 


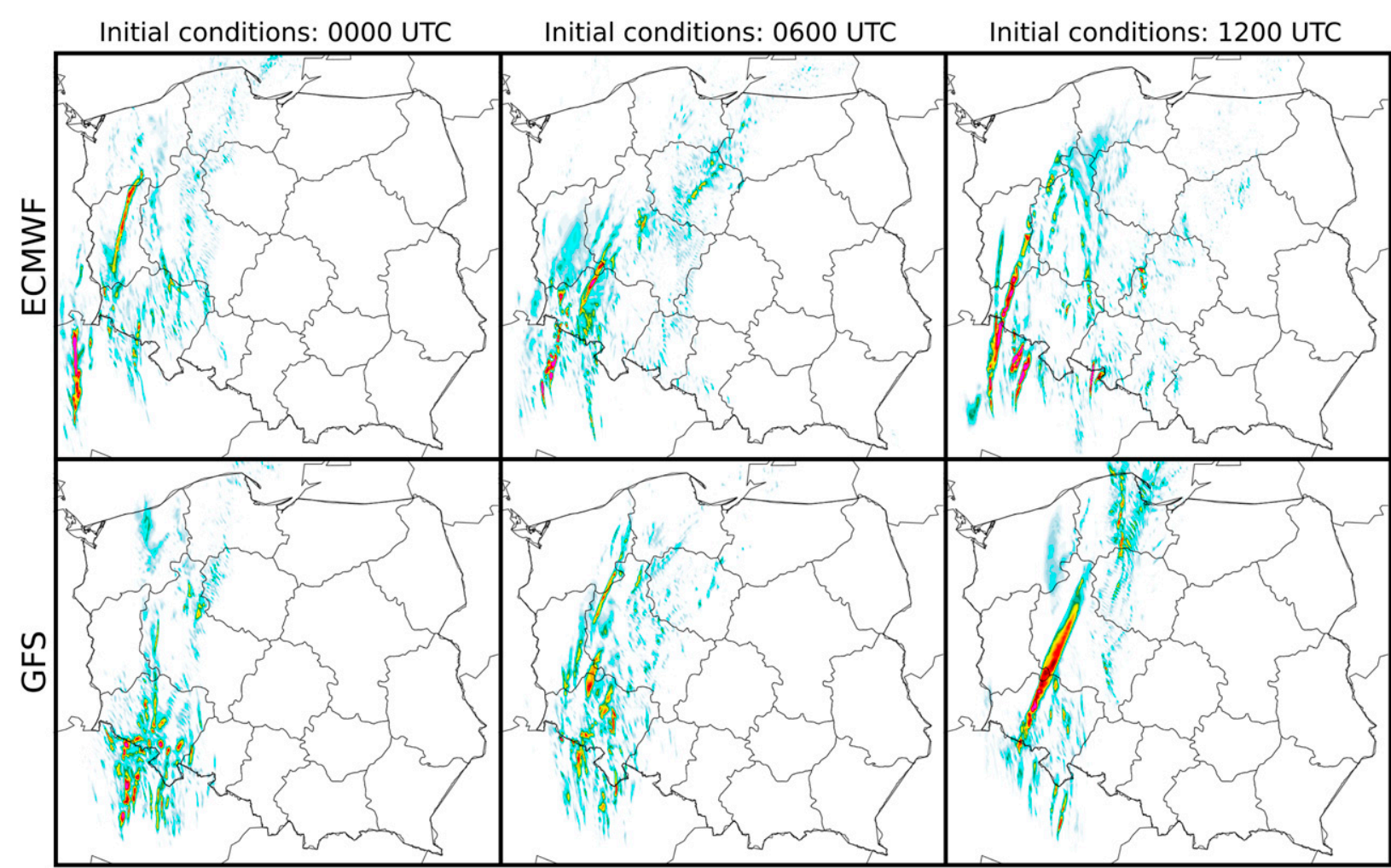

Updraft helicity swaths between 1200 and 0000 UTC on $11.08 .2017\left[\mathrm{~m}^{2} \mathrm{~s}^{-2}\right]$ (WRF downscalling to $1.2 \mathrm{~km}$ grid)

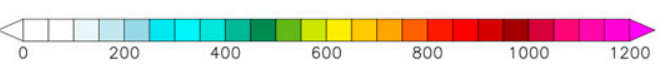

FIG. 16. Simulated 2-5 km AGL updraft helicity swaths between 1200 and 0000 UTC from WRF downscaling simulation to $1.2-\mathrm{km}$ grid within the initial conditions of: (top) ECMWF and (bottom) GFS for (left) 0000 UTC, (middle) 0600 UTC, and (right) 1200 UTC 11 Aug 2017.

well-developed bow echo, stronger $10 \mathrm{~m}$ AGL peak wind gusts (especially in the early stages), and a faster motion compared to the observed event. GFS-based simulation indicated overall weaker wind gusts but highlighted the highest threat from winds $\left(25-30 \mathrm{~m} \mathrm{~s}^{-1}\right)$ in north-central Poland (Fig. 17). Both GFS and ECMWF again indicated the possibility of supercells in the early stages of the MCS in southwestern Poland (Fig. 16).

Simulations based on the initial conditions a few hours before the formation of the MCS indicated a strong supercell and a bow echo developing on its eastern flank (Fig. 15). This scenario was consistent with the radar observations even though a simulated supercell was located too far to the west. These simulations contained a correction of cloudiness (Figs. 1 and 18), and therefore better sampled a preconvective environment and MCS placement. The ECMWF scenario, similar to previous simulations, indicated an aggressive development of a broad convective line with damaging wind gusts locally exceeding $35 \mathrm{~m} \mathrm{~s}^{-1}$ (Fig. 17) and a comma echo in the mature stage (2000-2100 UTC; Fig. 15). However, compared to the observations, the system was overdeveloped and moved too fast. The MCS simulated within the GFS initial conditions had a better timing and placement of $10 \mathrm{~m}$ AGL peak wind gusts. The simulation predicted a strong RIJ descending behind the bow echo (Fig. 19), which in north-central Poland resulted in winds exceeding $40 \mathrm{~m} \mathrm{~s}^{-1}$. Moreover, a path of wind gusts exceeding $25 \mathrm{~m} \mathrm{~s}^{-1}$ was in relative good agreement with the observed wind reports (Figs. 7 and 17).

All simulations indicated a large MCS with embedded supercells sweeping through the western parts of Poland and generating widespread severe wind gusts. Within each update, the forecast of MCS placement and peak wind gusts was more accurate. This highlights the importance of lateral/boundary conditions and initialization time in sampling such events. The correction in a cloud cover at 1200 UTC allowed to better predict placement of convective initialization and MCS evolution. As suggested by Ulmer and Balss (2016) WRF Model should run much earlier to allow spinup. However, in our case at 1200 UTC the model started only $3 \mathrm{~h}$ before the MCS. A strong synoptic-scale lift could have 


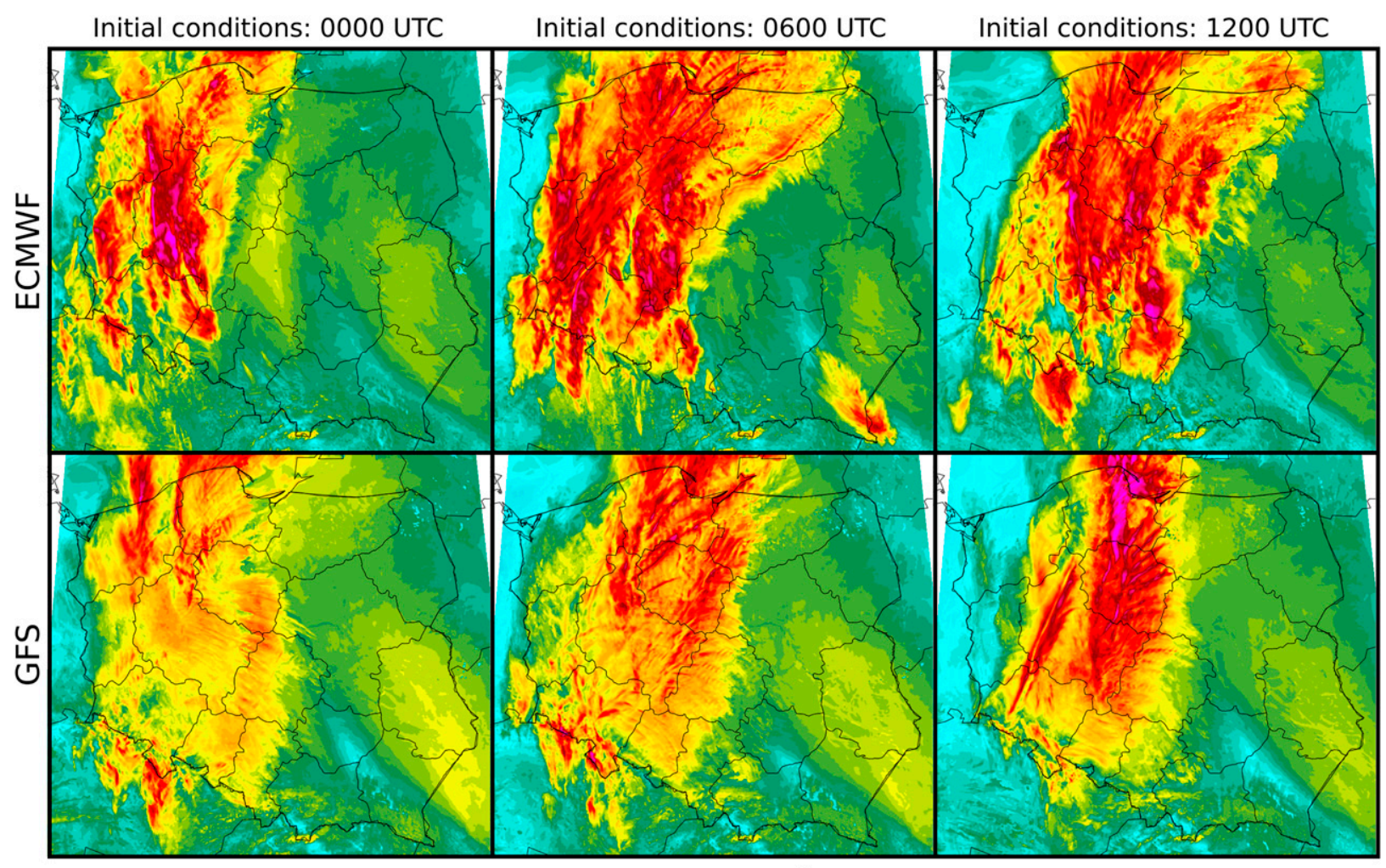

Peak $10 \mathrm{~m} \mathrm{AGL}$ wind gusts between 1200 and 0000 UTC on $11.08 .2017\left[\mathrm{~m} \mathrm{~s}^{-1}\right]$ (WRF downscalling to $1.2 \mathrm{~km}$ grid)

FIG. 17. Simulated peak $10 \mathrm{~m}$ AGL wind gusts between 1200 and 0000 UTC from WRF downscaling simulation to 1.2-km grid within the initial conditions of (top) ECMWF and (bottom) GFS for (left) 0000 UTC, (middle) 0600 UTC, and (right) 1200 UTC 11 Aug 2017.

been a factor that supported early convective initiation in the simulation.

\section{Discussion and conclusions}

This study documents the atmospheric conditions, development and evolution of a severe weather outbreak that occurred in the evening of 11 August 2017 in Poland. The emphasis is on analyzing system morphology and highlighting the importance of a mesovortex in producing the most significant wind damage. In addition, high-resolution simulations are performed within the use of initial conditions derived from GFS and ECMWF global models in order to assess whether it was possible to predict this event.

The derecho-producing MCS had a remarkable intensity and was probably one of the most impactful convective storms in the history of Poland. The MCS caused widespread damage in the area extending from northwestern Czech Republic to north-central Poland. In total, 1182 wind reports within this system were inserted into the ESWD. The storm system destroyed and partially damaged 79700 ha of forest $\left(9.8\right.$ million $\mathrm{m}^{3}$ of wood). It also damaged roughly 20000 buildings and cut off power to around 500000 customers. Moreover, 6 people lost their lives and another 58 were injured in that event.

The system developed in an environment of a very high vertical wind shear (especially considering 0-3-km layer: $20-25 \mathrm{~m} \mathrm{~s}^{-1}$ ), moderate thermodynamic instability (MU CAPE: 1000-2500 $\mathrm{J} \mathrm{kg}^{-1}$ ), rich boundary layer moisture (mixing ratio: $12-14 \mathrm{~g} \mathrm{~kg}^{-1}$ ), and high tropospheric moisture (precipitable water: $40-46 \mathrm{~mm}$ ). Although moisture and instability variables were not surprising for August given the climatology of central Europe (Taszarek et al. 2018), the MLS in this event was exceptionally high. This is also confirmed by CelińskiMysław et al. (2018) who evaluated thermodynamic and kinematic conditions of 91 bow echo cases in Poland and derived a mean of $13 \mathrm{~g} \mathrm{~kg}^{-1}$ mixing ratio, $1750 \mathrm{~J} \mathrm{~kg}^{-1}$ MU CAPE, and $15 \mathrm{~m} \mathrm{~s}^{-1}$ MLS (much lower than in our case) per bow echo event. Many studies pointed that high values of wind shear in the layer of $0-3$ and $0-1 \mathrm{~km}$ AGL may be conducive to the formation of strong and persistent mesovortices with damaging wind potential (Weisman and Trapp 2003; Atkins and St. Laurent 


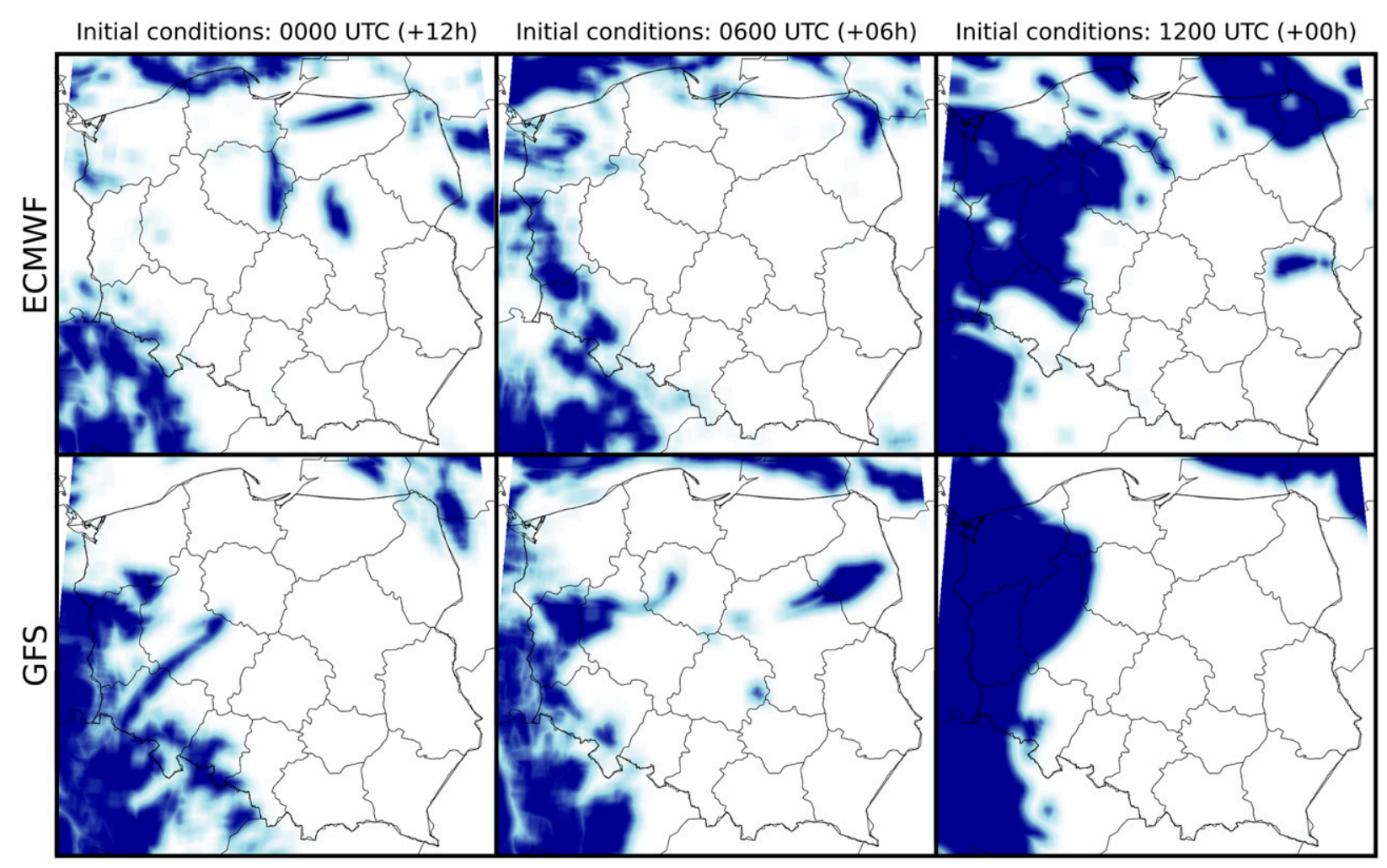

Total cloud cover at 1200 UTC on 11.08 .2017 in different simulations [\%] (WRF downscalling to $1.2 \mathrm{~km}$ grid)

FIG. 18. Simulated total cloud cover at 1200 UTC ( $3 \mathrm{~h}$ before convective initiation) from WRF downscaling simulation to $1.2-\mathrm{km}$ grid within the initial conditions of (top) ECMWF and (bottom) GFS for (left) 0000 UTC, (middle) 0600 UTC, and (right) 1200 UTC 11 Aug 2017. Please note that satellite image from the same date and hour is provided in Fig. $1 \mathrm{~b}$.

2009a; Weisman et al. 2013). Analysis of our case seems to confirm these findings, as a long-lived mesovortex was embedded in the MCS. Although more than 10 bow echoes occur each year in Poland, it is unusual to observe supercells growing upscale to line-end vortices in bow echo events.

Very moist air mass ahead of the system provided consistent access to large amounts of latent heat released into the cloud and intensified upward mass fluxes (James and Markowski 2010). Radar reflectivity exceeding $60 \mathrm{~dB} Z$ indicates that strong hydrometeor production was available in our case to drive powerful downdrafts. Given the remarkable wind damage, not without significance was also the fact that a vertical profile of the wind was supportive of a strong mesocyclones (clockwise-curved hodographs with $0-3-\mathrm{km}$ storm relative helicity ranging from 200 to $600 \mathrm{~m}^{2} \mathrm{~s}^{-2}$ ). Analysis of the radar images indicated that a supercell that developed in the early stages of the convective line had a big influence on the damage inflicted and evolution of the MCS. At around 1900-2000 UTC, the RFD from the mesocyclone interacted with RIJ and developed a large bow echo. The supercell itself evolved into a bookend vortex and later into a comma echo with embedded MCV. Swaths with extreme damage followed the mesocyclone in the early stages, and the MCV in the mature stage. The damage track broadened to the east of the vortex at the time when the mesocyclone evolved into the MCV. This indicates that a mesovortex and descending RIJ on its eastern flank were responsible for the most significant wind damage. A considerably lower number of severe wind events were reported in the central and eastern parts of the bow echo. This finding is in agreement with a study by Xu et al. (2015a,b), who also suggested that mesovortices on the edge of bow echo may cause RIJ to descend and subsequently produce damaging winds. The importance of mesovortices in producing extreme wind damage within MCSs was also found by Miller and Johns (2000), Weisman and Trapp (2003), Davis et al. (2004), Atkins et al. (2004, 2005), Wakimoto et al. (2006a,b), Wheatley et al. (2006), Atkins and St. Laurent (2009a,b), and Coniglio et al. (2011). Interaction of a squall line with a supercell resulting in a damaging surface winds was also confirmed by French and Parker (2014). 

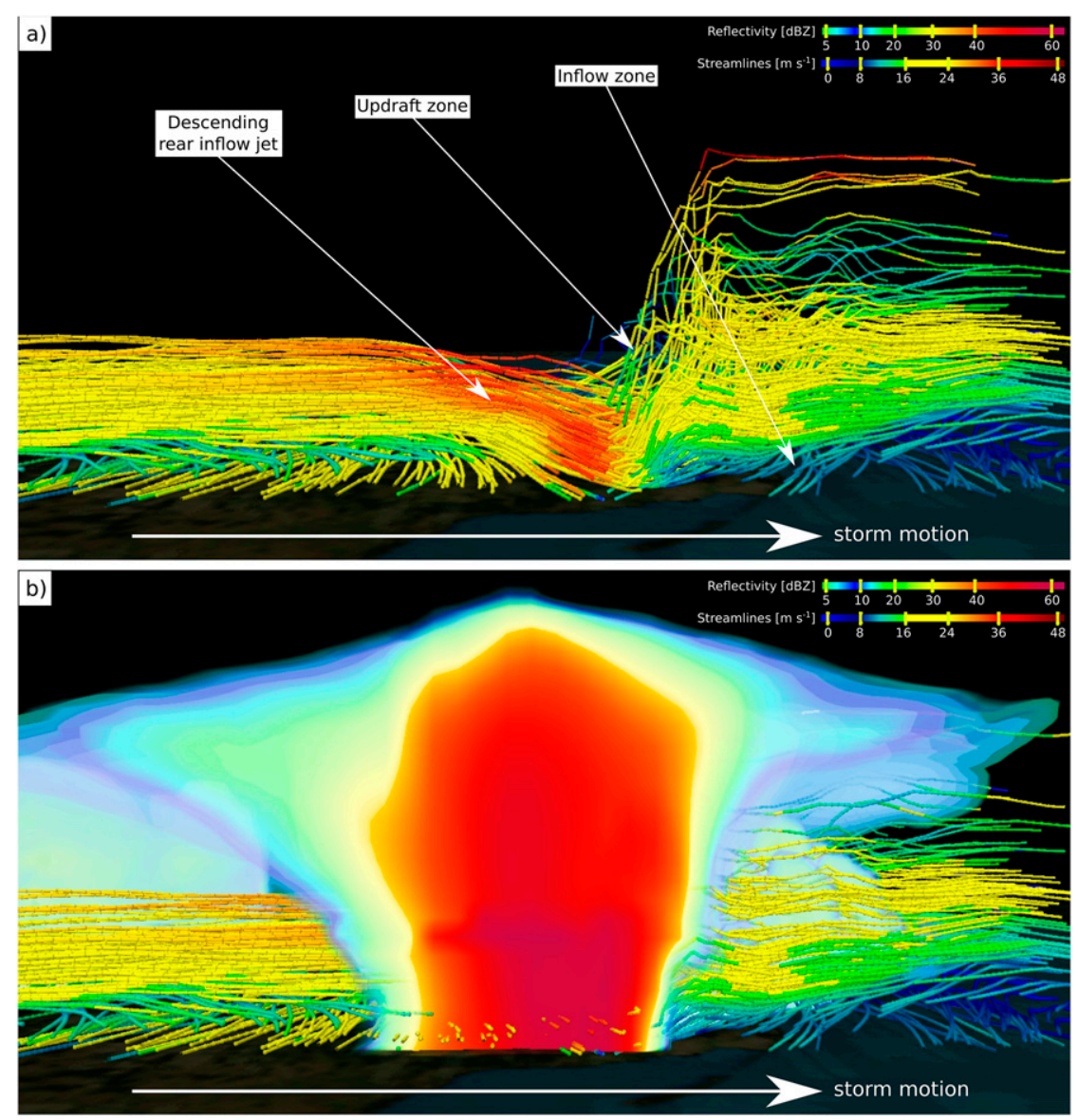

FIG. 19. Cross section through a bow echo apex (view from the east) along the $18.25^{\circ} \mathrm{E}$ meridian and 2300 UTC from downscaling simulation $(1.2 \mathrm{~km})$ based on the initial conditions from 1200 UTC GFS (north-central Poland; Fig. 15). (a) 0-3 km AGL streamlines with wind speed, (b) as in (a) but with the added reflectivity.

Numerical simulations involving downscaling to a convection-permitting resolution made it possible to successfully predict a large MCS sweeping through the western parts of Poland and generating widespread severe wind gusts. Within each update of the initial conditions, placements of the system and peak wind gusts were more accurate, especially after the update at 1200 UTC that indicated a proper cloud cover over western Poland. Simulations performed with latest initial conditions would have provided an important guideline to forecasters and emergency managers, indicating the areas most exposed to the damaging winds. All ECMWF-based simulations indicated the possibility of surface wind reaching extreme intensity. The most recent GFS update successfully pointed out that north-central Poland is the most endangered area with a potential wind gusts exceeding $40 \mathrm{~m} \mathrm{~s}^{-1}$. Unfortunately, the high demand for computational power in such simulations and limitations associated with the assimilation of observational data-inducing time lag preclude both spatial and temporal extent of their use in operational forecasting (Allen 2018). However, along with the increasing importance of remote sensing data and improvements in computational capabilities, such simulations should become more reliable in the not-too-distant future.

Although the intensity of this MCS may suggest that this was an extremely rare phenomenon, increasing thunderstorm frequency and intensity as a consequence of changing climate may mean that severe weather outbreaks will become more commonplace in the future (Brooks 2013; Trapp et al. 2007; Púčik et al. 2017; Allen 2018; Taszarek et al. 2019). A better understanding of the convective morphology and environment that lead to the development of such derecho-producing MCS will allow for a better prediction and monitoring of similar events in the foreseeable future.

Acknowledgments. This research was supported by grants of the Polish National Science Centre (Projects: 
2017/27/B/ST10/00297 and 2015/19/B/ST10/02158). We thank ECMWF and NOAA NCEP for providing NWP data. A support of Polish Institute of Meteorology and Water Management-National Research Institute is also greatly appreciated.

\section{REFERENCES}

Adlerman, E. J., K. K. Droegemeier, and R. Davies-Jones, 1999: A numerical simulation of cyclic mesocyclogenesis. J. Atmos. Sci., 56, 2045-2069, https://doi.org/10.1175/1520-0469(1999) $056<2045$ :ANSOCM $>2.0$. CO 2 .

Allen, J. T., 2018: Climate change and severe thunderstorms. $O x$ ford Research Encyclopedia of Climate Science, H. Von Storch et al., Eds., Oxford University Press, 1-37, https://doi.org/ 10.1093/acrefore/9780190228620.013.62.

Ashley, W. S., and T. L. Mote, 2005: Derecho hazards in the United States. Bull. Amer. Meteor. Soc., 86, 1577-1592, https://doi.org/ 10.1175/BAMS-86-11-1577.

Atkins, N. T., and M. St. Laurent, 2009a: Bow echo mesovortices. Part I: Processes that influence their damaging potential. Mon. Wea. Rev., 137, 1497-1513, https://doi.org/10.1175/ 2008MWR2649.1.

$\longrightarrow$, and $\longrightarrow$ 2009b: Bow echo mesovortices. Part II: Their genesis. Mon. Wea. Rev., 137, 1514-1532, https://doi.org/ 10.1175/2008MWR2650.1.

—, J. M. Arnott, R. W. Przybylinski, R. A. Wolf, and B. D. Ketcham, 2004: Vortex structure and evolution within bow echoes. Part I: Single-Doppler and damage analysis of the 29 June 1998 derecho. Mon. Wea. Rev., 132, 2224-2242, https://doi.org/ 10.1175/1520-0493(2004)132<2224:VSAEWB >2.0.CO;2.

- - C. S. Bouchard, R. W. Przybylinski, R. J. Trapp, and G. Schmocker, 2005: Damaging surface wind mechanisms within the 10 June 2003 Saint Louis bow echo during BAMEX. Mon. Wea. Rev., 133, 2275-2296, https://doi.org/10.1175/ MWR2973.1.

Bentley, M. L., and T. L. Mote, 1998: A climatology of derechoproducing mesoscale convective systems in central and eastern United States, 1986-95. Part I: Temporal and spatial distribution. Bull. Amer. Meteor. Soc., 79, 2527-2540, https://doi.org/ 10.1175/1520-0477(1998)079<2527:ACODPM>2.0.CO;2.

Bluestein, H. B., and M. H. Jain, 1985: Formation of mesoscale lines of precipitation: Severe squall lines in Oklahoma during the spring. J. Atmos. Sci., 42, 1711-1732, https://doi.org/ 10.1175/1520-0469(1985)042<1711:FOMLOP > 2.0.CO;2.

Boville, B. A., P. J. Rasch, J. J. Hack, and J. R. McCaa, 2006: Representation of clouds and precipitation processes in the Community Atmosphere Model version 3 (CAM3). J. Climate, 19, 2184-2198, https://doi.org/10.1175/JCLI3749.1.

Brooks, H. E., 2013: Severe thunderstorms and climate change. Atmos. Res., 123, 129-138, https://doi.org/10.1016/j.atmosres.2012.04.002.

— draft intensity in numerically modeled supercells. J. Atmos. Sci., 50, 1824-1833, https://doi.org/10.1175/1520-0469(1993) $050<1824:$ HCAUII $>2.0$. CO; 2 .

Bunkers, M. J., B. A. Klimowski, J. W. Zeitler, R. L. Thompson, and M. L. Weisman, 2000: Predicting supercell motion using a new hodograph technique. Wea. Forecasting, 15, 61-79, https://doi.org/ 10.1175/1520-0434(2000)015<0061:PSMUAN > 2.0.CO;2.

Celiński-Mysław, D., and D. Matuszko, 2014: An analysis of selected cases of derecho in Poland. Atmos. Res., 149, 263-281, https://doi.org/10.1016/j.atmosres.2014.06.016.
- and A. Palarz, 2017: The occurrence of convective systems with a bow echo in warm season in Poland. Atmos. Res., 193, 26-35, https://doi.org/10.1016/j.atmosres.2017.04.015.

——, - and Ł. Łoboda, 2018: Kinematic and thermodynamic conditions related to convective systems with a bow echo in Poland. Theor. Appl. Climatol., https://doi.org/10.1007/ s00704-018-2728-6, in press.

Clark, A. J., W. A. Gallus Jr., M. Xue, and F. Kong, 2009: A comparison of precipitation forecast skill between small convection-allowing and large convection-parameterizing ensembles. Wea. Forecasting, 24, 1121-1140, https://doi.org/ 10.1175/2009WAF2222222.1.

Clyne, J., P. Mininni, A. Norton, and M. Rast, 2007: Interactive desktop analysis of high resolution simulations: Application to turbulent plume dynamics and current sheet formation. New J. Phys., 9, 301, https://doi.org/10.1088/ 1367-2630/9/8/301.

Cohen, A. E., M. C. Coniglio, S. F. Corfidi, and S. J. Corfidi, 2007: Discrimination of mesoscale convective system environments using sounding observations. Wea. Forecasting, 22, 1045-1062, https://doi.org/10.1175/WAF1040.1.

Coniglio, M. C., and D. J. Stensrud, 2001: Simulation of a progressive derecho using composite initial conditions. Mon. Wea. Rev., 129, 1593-1616, https://doi.org/10.1175/1520-0493(2001)129<1593: SOAPDU $>2.0 . \mathrm{CO} ; 2$.

Wea. Forecasting, 19, 595-605, https://doi.org/10.1175/15200434(2004)019<0595:ITCOD>2.0.CO;2.

— H. E. Brooks, S. J. Weiss, and S. F. Corfidi, 2007: Forecasting the maintenance of quasi-linear mesoscale convective systems. Wea. Forecasting, 22, 556-570, https://doi.org/10.1175/ WAF1006.1.

, J. Y. Hwang, and D. J. Stensrud, 2010: Environmental factors in the upscale growth and longevity of MCSs derived from rapid update cycle analyses. Mon. Wea. Rev., 138, 3514-3539, https://doi.org/10.1175/2010MWR3233.1.

— S. F. Corfidi, and J. S. Kain, 2011: Environment and early evolution of the 8 May 2009 derecho-producing convective system. Mon. Wea. Rev., 139, 1083-1102, https://doi.org/ 10.1175/2010MWR3413.1.

Corfidi, S. F., M. C. Coniglio, A. E. Cohen, and C. M. Mead, 2016: A proposed revision to the definition of "derecho." Bull. Amer. Meteor. Soc., 97, 935-949, https://doi.org/10.1175/ BAMS-D-14-00254.1.

Craven, J. P., and H. E. Brooks, 2004: Baseline climatology of sounding derived parameters associated with deep moist convection. Natl. Wea. Dig., 28, 13-24, http://www.nssl.noaa.gov/ users/brooks/public_html/papers/cravenbrooksnwa.pdf.

Davies-Jones, R. P., 1982a: A new look at the vorticity equation with application to tornadogenesis. Preprints, 12th Conf. on Severe Local Storms, San Antonio, TX, Amer. Meteor. Soc., 249-252.

- 1982b: Observational and theoretical aspects of tornadogenesis. Intense Atmospheric Vortices, L. Bengtsson and J. Lighthill, Eds., Springer-Verlag, 175-189.

Davis, C. A., and S. B. Trier, 2007: Mesoscale convective vortices observed during BAMEX. Part I: Kinematic and thermodynamic structure. Mon. Wea. Rev., 135, 2029-2049, https:// doi.org/10.1175/MWR3398.1.

- and Coauthors, 2004: The Bow Echo and MCV Experiment (BAMEX): Observations and opportunities. Bull. Amer. Meteor. Soc., 85, 1075-1093, https://doi.org/10.1175/BAMS85-8-1075. 
Doswell, C. A., III, and D. W. Burgess, 1993: Tornadoes and tornadic storms: A review of conceptual models. The Tornado: Its Structure, Dynamics, Prediction, and Hazards, C. Church et al., Eds., Amer. Geophys. Union, 161-172.

, and J. S. Evans, 2003: Proximity sounding analysis for derechos and supercells: An assessment of similarities and differences. Atmos. Res., 67-68, 117-133, https://doi.org/10.1016/ S0169-8095(03)00047-4.

—, H. E. Brooks, and R. A. Maddox, 1996: Flash flood forecasting: An ingredients-based methodology. Wea. Forecasting, 11, 560-580, https://doi.org/10.1175/1520-0434(1996)011<0560: FFFAIB $>2.0 . \mathrm{CO} ; 2$.

Dotzek, N., P. Groenemeijer, B. Feuerstein, and A. M. Holzer, 2009: Overview of ESSL's severe convective storms research using the European Severe Weather Database ESWD. Atmos. Res., 93, 575-586, https://doi.org/10.1016/ j.atmosres.2008.10.020.

Evans, J. S., and C. A. Doswell III, 2001: Examination of derecho environments proximity soundings. Wea. Forecasting, 16, 329-342, https://doi.org/10.1175/1520-0434(2001)016<0329: EODEUP $>2.0 . \mathrm{CO} ; 2$.

French, A. J., and M. D. Parker, 2014: Numerical simulations of bow echo formation following a squall line-supercell merger. Mon. Wea. Rev., 142, 4791-4822, https://doi.org/10.1175/MWR-D-13-00356.1.

Fujita, T. T., 1971: Proposed characterization of tornadoes and hurricanes by area and intensity. SMRP Research Paper, Vol. 91, University of Chicago, 45 pp.

, 1978: Manual of downburst identification for Project NIMROD. Satellite and Mesometeorology Research Paper, Vol. 156, University of Chicago, 104 pp.

_ 1979: Objective, operation, and results of Project NIMROD. Preprints, 11th Conf. on Severe Local Storms, Kansas City, MO, Amer. Meteor. Soc., 259-266.

Funk, T. W., K. E. Darmofal, J. D. Kirkpatrick, V. L. DeWald, R. W. Przybylinski, G. K. Schmocker, and Y.-J. Lin, 1999: Storm reflectivity and mesocyclone evolution associated with the 15 April 1994 squall line over Kentucky and southern Indiana. Wea. Forecasting, 14, 976-993, https://doi.org/10.1175/ 1520-0434(1999)014<0976:SRAMEA >2.0.CO;2.

Gatzen, C., 2004: A derecho in Europe: Berlin, 10 July 2002. Wea. Forecasting, 19, 639-645, https://doi.org/10.1175/1520-0434(2004) 019<0639:ADIEBJ > 2.0.CO;2.

- 2013: Warm-season severe wind events in Germany. Atmos. Res., 123, 197-205, https://doi.org/10.1016/j.atmosres.2012.07.017.

—, T. Púčik, and D. Ryva, 2011: Two cold-season derechoes in Europe. Atmos. Res., 100, 740-748, https://doi.org/10.1016/ j.atmosres.2010.11.015.

Gospodinov, I., T. Dimitrova, L. Bocheva, P. Simeonov, and R. Dimitrov, 2015: Derecho-like event in Bulgaria on 20 July 2011. Atmos. Res., 158-159, 254-273, https://doi.org/10.1016/ j.atmosres.2014.05.009.

Grim, J. A., R. M. Rauber, G. M. McFarquhar, B. F. Jewett, and D. P. Jorgensen, 2009: Development and forcing of the rear inflow jet in a rapidly developing and decaying squall line during BAMEX. Mon. Wea. Rev., 137, 1206-1229, https:// doi.org/10.1175/2008MWR2503.1.

Grunzke, C. T., and C. Evans, 2017: Predictability and dynamics of warm-core mesoscale vortex formation with the 8 May 2009 “Super Derecho" event. Mon. Wea. Rev., 145, 811-832, https:// doi.org/10.1175/MWR-D-16-0217.1.

Guastini, C. T., and L. F. Bosart, 2016: Analysis of a progressive derecho climatology and associated formation environments. Mon. Wea. Rev., 144, 1363-1382, https://doi.org/10.1175/MWR-D-15-0256.1.
Hamid, K., 2012: Investigation of the passage of the derecho in Belgium. Atmos. Res., 107, 86-105, https://doi.org/10.1016/ j.atmosres.2011.12.013.

Hong, S.-Y., and J.-O. J. Lim, 2006: The WRF single-moment 6-class microphysics scheme (WSM6). J. Korean Meteor. Soc., 42, 129-151.

—-, Y. Noh, and J. Dudhia, 2006: A new vertical diffusion package with an explicit treatment of entrainment processes. Mon. Wea. Rev., 134, 2318-2341, https://doi.org/10.1175/ MWR3199.1.

Houze, R. A., Jr., 1993: Cloud Dynamics. Academic Press, 573 pp. - 2004: Mesoscale convective systems. Rev. Geophys., 42, RG4003, https://doi.org/10.1029/2004RG000150.

James, R. P., and P. M. Markowski, 2010: A numerical investigation of the effects of dry air aloft on deep convection. Mon. Wea. Rev., 138, 140-161, https://doi.org/10.1175/ 2009MWR3018.1.

Johns, R. H., 1993: Meteorological conditions associated with bow echo development in convective storms. Wea. Forecasting, 8, 294-299, https://doi.org/10.1175/1520-0434(1993)008<0294: MCAWBE $>2.0 . \mathrm{CO} ; 2$.

— duced windstorms. Wea. Forecasting, 2, 32-49, https://doi.org/ 10.1175/1520-0434(1987)002<0032:DWCIW>2.0.CO;2.

Kain, J. S., S. J. Weiss, J. J. Levit, M. E. Baldwin, and D. R. Bright, 2006: Examination of convection-allowing configurations of the WRF Model for the prediction of severe convective weather: The SPC/NSSL Spring Program 2004. Wea. Forecasting, 21, 167-181, https://doi.org/10.1175/WAF906.1.

_ , and Coauthors, 2008: Some practical considerations regarding horizontal resolution in the first generation of operational convection-allowing NWP. Wea. Forecasting, 23, 931-952, https://doi.org/10.1175/WAF2007106.1.

Kuchera, E. L., and M. D. Parker, 2006: Severe convective wind environments. Wea. Forecasting, 21, 595-612, https://doi.org/ 10.1175/WAF931.1.

Kühnlein, C., C. Keil, G. C. Craig, and C. Gebhardt, 2014: The impact of downscaled initial condition perturbations on convective-scale ensemble forecasts of precipitation. Quart. J. Roy. Meteor. Soc., 140, 1552-1562, https://doi.org/10.1002/ qj. 2238 .

Lawson, J., and W. A. Gallus Jr., 2016: On contrasting ensemble simulations of two Great Plains bow echoes. Wea. Forecasting, 31, 787-810, https://doi.org/10.1175/WAF-D-15-0060.1.

Leutwyler, D., O. Fuhrer, X. Lapillonne, D. Lüthi, and C. Schär, 2016: Towards European-scale convection-resolving climate simulations with GPUs: A study with COSMO 4.19. Geosci. Model Dev., 9, 3393-3412, https://doi.org/10.5194/gmd-9-33932016.

López, J. M., 2007: A Mediterranean derecho: Catalonia (Spain), 17th August 2003. Atmos. Res., 83, 272-283, https://doi.org/ 10.1016/j.atmosres.2005.08.008.

Maddox, R. A., L. R. Hoxit, and C. F. Chappell, 1980: A study of tornadic thunderstorms interactions with thermal boundaries. Mon. Wea. Rev., 108, 1866-1877, https://doi.org/10.1175/15200493(1980)108<1866:MCOFFE > 2.0.CO;2.

Markowski, P. M., 2002: Hook echoes and rear-flank downdrafts: A review. Mon. Wea. Rev., 130, 852-876, https://doi.org/10.1175/ 1520-0493(2002)130<0852:HEARFD>2.0.CO;2.

_ tornadoes in supercells interacting with boundaries. Wea. Forecasting, 13, 852-859, https://doi.org/10.1175/1520-0434(1998) $013<0852$ :TOOTIS $>2.0$.CO;2. 
Mathias, L., V. Ermert, F. D. Kelemen, P. Ludwig, and J. G. Pinto, 2017: Synoptic analysis and hindcast of an intense bow echo in western Europe: The 9 June 2014 storm. Wea. Forecasting, 32, 1121-1141, https://doi.org/10.1175/WAF-D-16-0192.1.

Melhauser, C., and F. Zhang, 2012: Practical and intrinsic predictability of severe and convective weather at the mesoscales. J. Atmos. Sci., 69, 3350-3371, https://doi.org/10.1175/JAS-D11-0315.1.

Meng, Z., F. Zhang, P. Markowski, D. Wu, and K. Zhao, 2012: A modeling study on the development of a bowing structure and associated rear inflow within a squall line over South China. J. Atmos. Sci., 69, 1182-1207, https://doi.org/10.1175/JAS-D11-0121.1.

Miller, D. J., and R. H. Johns, 2000: A detailed look at extreme wind damage in derecho events. Preprints, 20th Conf. on Severe Local Storms, Orlando, FL, Amer. Meteor. Soc., 52-55.

NCEP/NWS/NOAA/U.S. Department of Commerce, 2015a: NCEP GDAS/FNL 0.25 degree global tropospheric analyses and forecast grids. Research Data Archive at the National Center for Atmospheric Research, Computational and Information Systems Laboratory, accessed 20 April 2018, https:// doi.org/10.5065/D65Q4T4Z.

- 2015b: NCEP GFS 0.25 degree global forecast grids historical archive. Research Data Archive at the National Center for Atmospheric Research, Computational and Information Systems Laboratory, accessed 20 April 2018, https://doi.org/ 10.5065/D65D8PWK.

Nolen, R. H., 1959: A radar pattern associated with tornadoes. Bull. Amer. Meteor. Soc., 40, 277-279, https://doi.org/10.1175/ 1520-0477-40.6.277.

Orlanski, I., 1975: A rational subdivision of scales for atmospheric processes. Bull. Amer. Meteor. Soc., 56, 527-530, https://doi.org/ 10.1175/1520-0477-56.5.527.

Ośródka, K., J. Szturc, and A. Jurczyk, 2014: Chain of data quality algorithms for 3-D single-polarization radar reflectivity (RADVOL-QC system). Meteor. Appl., 21, 256-270, https:// doi.org/10.1002/met.1323.

Parker, M. D., and R. H. Johnson, 2000: Organizational modes of midlatitude mesoscale convective systems. Mon. Wea. Rev., 128, 3413-3436, https://doi.org/10.1175/1520-0493(2001) 129<3413:OMOMMC $>2.0 . \mathrm{CO} ; 2$.

Pilguj, N., M. Taszarek, Ł. Pajurek, and M. Kryza, 2019: Highresolution simulation of an isolated tornadic supercell in Poland on 20 June 2016. Atmos. Res., 218, 145-159, https:// doi.org/10.1016/j.atmosres.2018.11.017.

Púčik, T., M. Francová, D. Rýva, M. Kolář, and L. Ronge, 2011: Forecasting challenges during the severe weather outbreak in Central Europe on 25 June 2008. Atmos. Res., 100, 680-704, https://doi.org/10.1016/j.atmosres.2010.11.014.

__, P. Groenemeijer, D. Rýva, and M. Kolár, 2015: Proximity soundings of severe and nonsevere thunderstorms in central Europe. Mon. Wea. Rev., 143, 4805-4821, https://doi.org/ 10.1175/MWR-D-15-0104.1.

— , and Coauthors, 2017: Future changes in European severe convection environments in a regional climate model ensemble. J. Climate, 30, 6771-6794, https://doi.org/10.1175/JCLI-D16-0777.1.

Punkka, A.-J., J. Teittinen, and R. H. Johns, 2006: Synoptic and mesoscale analysis of a high-latitude derecho-severe thunderstorm outbreak in Finland on 5 July 2002. Wea. Forecasting, 21, 752-763, https://doi.org/10.1175/WAF953.1.

Rasmussen, E. N., and D. O. Blanchard, 1998: A baseline climatology of sounding-derived supercell and tornado forecast parameters. Wea. Forecasting, 13, 1148-1164, https://doi.org/ 10.1175/1520-0434(1998)013<1148:ABCOSD>2.0.CO;2.

_, S. Richardson, J. M. Straka, P. M. Markowski, and D. O. Blanchard, 2000: The association of significant tornadoes with a baroclinic boundary on 2 June 1995. Mon. Wea. Rev., 128, 174-191, https:// doi.org/10.1175/1520-0493(2000)128<0174:TAOSTW>2.0.CO;2.

Schenkman, A. D., and M. Xue, 2016: Bow-echo mesovortices: A review. Atmos. Res., 170, 1-13, https://doi.org/10.1016/ j.atmosres.2015.11.003.

Selex, 2010: Rainbow 5: Products and algorithms. Release 5.31.0. Selex SI GmbH, Neuss, 442 pp.

Simon, A., J. Kaňák, A. Sokol, M. Putsay, L. Uhrínová, K. Csirmaz, L. Okon, and R. Habrovský, 2011: Case study of a severe windstorm over Slovakia and Hungary on 25 June 2008. Atmos. Res., 100, 705-739, https://doi.org/10.1016/ j.atmosres.2010.12.012.

Skamarock, W. C., M. L. Weisman, and J. B. Klemp, 1994: Three dimensional evolution of simulated long-lived squall lines. J. Atmos. Sci., 51, 2563-2584, https://doi.org/10.1175/15200469(1994)051<2563:TDEOSL > 2.0.CO;2.

, and Coauthors, 2008: A description of the Advanced Research WRF version 3. NCAR Tech. Note NCAR/TN475+STR, 113 pp., https://doi.org/10.5065/D68S4MVH.

Snively, D. V., and W. A. Gallus Jr., 2014: Prediction of convective morphology in near-cloud-permitting WRF model simulations. Wea. Forecasting, 29, 130-149, https://doi.org/10.1175/ WAF-D-13-00047.1.

Taszarek, M., B. Czernecki, and A. Kozioł, 2015: A cloud-toground lightning climatology for Poland. Mon. Wea. Rev., 143, 4285-4304, https://doi.org/10.1175/MWR-D-15-0206.1.

$\_,-$S. Walczakiewicz, A. Mazur, and L. Kolendowicz, 2016: An isolated tornadic supercell of 14 July 2012 in Poland-A prediction technique within the use of coarse-grid WRF simulation. Atmos. Res., 178-179, 367-379, https://doi.org/ 10.1016/j.atmosres.2016.04.009.

— H. E. Brooks, and B. Czernecki, 2017: Sounding-derived parameters associated with convective hazards in Europe. Mon. Wea. Rev., 145, 1511-1528, https://doi.org/10.1175/ MWR-D-16-0384.1.

,,$--\longrightarrow$, P. Szuster, and K. Fortuniak, 2018: Climatological aspects of convective parameters over Europe: A comparison of ERA-Interim and sounding data. J. Climate, 31, 4281-4308, https://doi.org/10.1175/JCLI-D-17-0596.1.

— , and Coauthors, 2019: A climatology of thunderstorms across Europe from a synthesis of multiple data sources. J. Climate, 32, 1813-1837, https://doi.org/10.1175/JCLI-D-18-0372.1.

Toll, V., A. Männik, A. Luhmaa, and R. Rõõm, 2015: Hindcast experiments of the derecho in Estonia on 08 August, 2010: Modeling derecho with NWP model HARMONIE. Atmos. Res., 158-159, 179-191, https://doi.org/10.1016/ j.atmosres.2014.10.011.

Trapp, R. J., and M. L. Weisman, 2003: Low-level mesovortices within squall lines and bow echoes. Part II: Their genesis and implications. Mon. Wea. Rev., 131, 2804-2823, https://doi.org/ 10.1175/1520-0493(2003)131<2804:LMWSLA > 2.0.CO;2.

, N. S. Diffenbaugh, H. E. Brooks, M. E. Baldwin, E. D. Robinson, and J. S. Pal, 2007: Changes in severe thunderstorm environment frequency during the 21 st century caused by anthropogenically enhanced global radiative forcing. Proc. Natl. Acad. Sci. USA, 104, 19719-19723, https://doi.org/10.1073/ pnas.0705494104.

Ulmer, F. G., and U. Balss, 2016: Spin-up time research on the weather research and forecasting model for atmospheric delay 
mitigations of electromagnetic waves. J. Appl. Remote Sens., 10, 016027, https://doi.org/10.1117/1.JRS.10.016027.

Wakimoto, R. M., H. V. Murphey, A. Nester, D. P. Jorgensen, and N. T. Atkins, 2006a: High winds generated by bow echoes. Part I: Overview of the Omaha bow echo 5 July 2003 storm during BAMEX. Mon. Wea. Rev., 134, 2793-2812, https://doi.org/10.1175/ MWR3215.1.

, - C. A. Davis, and N. T. Atkins, 2006b: High winds generated by bow echoes. Part II: The relationship between the mesovortices and damaging straight-line winds. Mon. Wea. Rev., 134, 2813-2829, https://doi.org/10.1175/MWR3216.1.

Walko, R. L., 1993: Tornado spin-up beneath a convective cell: Required basic structure of the near-field boundary layer winds. The Tornado: Its Structure, Dynamics, Prediction, and Hazards, C. Church et al., Eds., Amer. Geophys. Union, 89-95.

Wandishin, M. S., D. J. Stensrud, S. L. Mullen, and L. J. Wicker, 2008: On the predictability of mesoscale convective systems: Two-dimensional simulations. Wea. Forecasting, 23, 773-785, https://doi.org/10.1175/2008WAF2007057.1.

,,,--- and,- 2010 : On the predictability of mesoscale convective systems: Three-dimensional simulations. Mon. Wea. Rev., 138, 863-885, https://doi.org/10.1175/ 2009MWR2961.1.

Warren, R. A., D. J. Kirshbaum, R. S. Plant, and H. W. Lean, 2014: A 'Boscastle-type' quasi-stationary convective system over the UK Southwest Peninsula. Quart. J. Roy. Meteor. Soc., 140, 240-257, https://doi.org/10.1002/qj.2124.

Weisman, M. L., 1992: The role of convectively generated rearinflow jets in the evolution of long lived mesoconvective systems. J. Atmos. Sci., 49, 1826-1847, https://doi.org/10.1175/ 1520-0469(1992)049<1826:TROCGR>2.0.CO;2.

- 1993: The genesis of severe, long lived bow echoes. J. Atmos. Sci., 50, 645-670, https://doi.org/10.1175/1520-0469(1993) $050<0645$ :TGOSLL $>2.0$.CO;2.

, and C. A. Davis, 1998: Mechanisms for the generation of mesoscale vortices within quasi-linear convective systems. J. Atmos. Sci., 55, 2603-2622, https://doi.org/10.1175/1520-0469(1998) 055<2603:MFTGOM>2.0.CO;2.
, and R. Rotunno, 2000: The use of vertical wind shear versus helicity in interpreting supercell dynamics. J. Atmos. Sci., 57, 1452-1472, https://doi.org/10.1175/1520-0469(2000)057<1452: TUOVWS $>2.0$.CO;2.

— , and - 2004: "A theory for strong long-lived squall lines" revisited. J. Atmos. Sci., 61, 361-382, https://doi.org/10.1175/ 1520-0469(2004)061<0361:ATFSLS>2.0.CO;2.

_ , and R. J. Trapp, 2003: Low-level mesovortices within squall lines and bow echoes. Part I: Overview and sensitivity to environmental vertical wind shear. Mon. Wea. Rev., 131, 2779-2803, https:// doi.org/10.1175/1520-0493(2003)131<2779:LMWSLA > 2.0.CO;2.

_ W. W. Skamarock, and J. B. Klemp, 1997: The resolution dependence of explicitly modeled convective systems. Mon. Wea. Rev., 125, 527-548, https://doi.org/10.1175/15200493(1997)125<0527:TRDOEM>2.0.CO;2.

_ C. A. Davis, W. Wang, K. W. Manning, and J. B. Klemp, 2008: Experiences with 0-36-h explicit convective forecasts with the WRF-ARW Model. Wea. Forecasting, 23, 407-437, https://doi.org/10.1175/2007WAF2007005.1.

_ C. Evans, and I. Bosart, 2013: The 8 May 2008 superderecho: Analysis of a real-time explicit convective forecast. Wea. Forecasting, 28, 863-892, https://doi.org/10.1175/WAF-D-1200023.1.

Wheatley, D. M., R. J. Trapp, and N. T. Atkins, 2006: Radar and damage analysis of severe bow echoes observed during BAMEX. Mon. Wea. Rev., 134, 791-806, https://doi.org/10.1175/ MWR3100.1.

Xu, X., M. Xue, and Y. Wang, 2015a: Mesovortices within the 8 May 2009 bow echo over the central United States: Analyses of the characteristics and evolution based on Doppler radar observations and a high-resolution model simulation. Mon. Wea. Rev., 143, 2266-2290, https://doi.org/10.1175/MWR-D-14-00234.1.

,$- \ldots$, and $-2015 \mathrm{~b}$ : The genesis of mesovortices within a real-data simulation of a bow echo system. J. Atmos. Sci., 72, 1963-1986, https://doi.org/10.1175/JAS-D-14-0209.1.

Zipser, E. J., 1982: Use of a conceptual model of the life cycle of mesoscale convective systems to improve very-short-range forecasts. Nowcasting, K. Browning, Ed., Academic Press, 191-221. 